一報 文一

リブ構造をむつ編布の構造モデルに関する研究

\begin{tabular}{|c|c|c|c|}
\hline 宗都大学工学部 & 川 & 端 & 李 \\
\hline 柰是女子大学 & 丹 & 羽 & 雅: \\
\hline 宗都大学工学部 & 河 & 今ิ & 弘 \\
\hline
\end{tabular}

\title{
Structure Models for Theoretical Analysis of the Uni- and Bi-axial Tensile Properties of Weft Knitted Fabrics Having a Rib Structure
}

\author{
Sueo Kawabata*, Masako Niwa** and Hiromichi Kawai* \\ *Department of Polymer Chemistry, Kyoto University, Kyoto \\ **Department of Clothing Science, Nara Women's University, Nara
}

\begin{abstract}
Structure models of weft knitted fabrics having a rib structure are presented here for the purpose of theoretical calculation of the tensile properties of the fabrics. Each of the models must have a simple structure to make the calculation be easy, also enough structure for accurate calculation.

In this paper, the models of $1 \times 1 \mathrm{rib}$ and interlock structures are presented and a simple method to decide their structure constants explained.

Firstly, the structure of each fabric in a critical state of deformation is exactly decided, and then the model for the bending effective region of stretching is derived from this structure. This model has such a simple structure that the yarns in the fabric are transformed to some elements of arc or column. And the deformation of this model by extension takes with bending of the arcs, twisting of the arcs and the columns and slippage between those elements in the bending effective region. And when the arcs are straightend, that is in the critical state of stretching, the structure of the model coincident with the structure in its critical state. This simplification will make easy the theoretical calculation of the tensile properties.

After the critical stretching, yarns of the model are generally stretched with slipping at the crossing point of yarns.

Using these models, the uni-and bi-axial tensile properties of the fabrics can be calculated if the yarn properties, e.g・, tensile, bending, torsional, frictional and compressive properties, are given.

The structure constants of the models can be derived from following structural constants of a given fabric. $W$ : the wales per $\mathrm{cm} ; C$ or $R$ : the courses or ribs per $\mathrm{cm} ; G$ : weight of fabrics per unit area ; $Y$ : linear density of yarn ; $Z_{f}$ : spacing between loops in front side; $Z_{b}$ : spacing between loops in back side; $d$ : mean diameter of fibers ; $N$ : mean number of fibers in the cross section of yarn.
\end{abstract}

(Received July 15, 1971)

\footnotetext{
摘 嘷

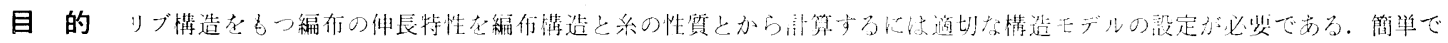

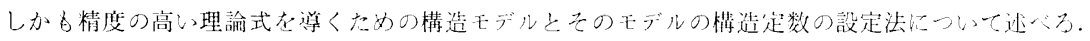

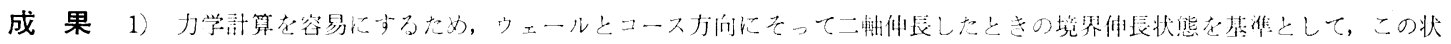

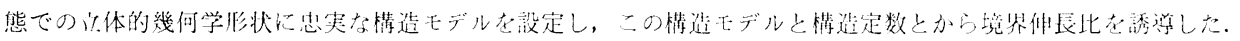

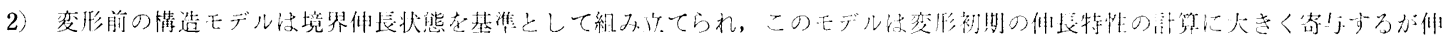

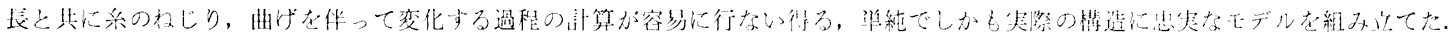

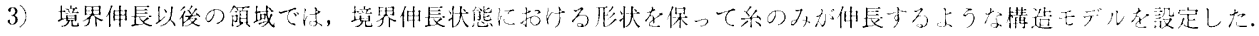

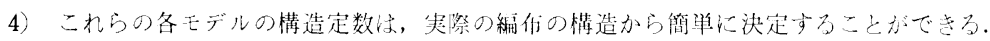




\section{1. 緒 言}

リブ構造をもつ編布を平編布上比較すると表赛編目を 結ぶリンクを持つたわ，その幾何学的構造は一層複雑で ある. 平編布の基本構造モデルはすでに報告し”，この 構造モデルが力学的性質の計算に妥当であることはすで に確認している2,3!

リブ構造をむつ編布についてむ，その伸長特性在編布 構造上杀の性質から計算し得る, 簡単加つ精度の高い理 論式を尊くための構造モデルの設定が必要である.これ が决まれば，すでに平編布などで試みられてきた方法に より直ちに引張特性が計算できる。

本報告では，精度よい理論計算を目的とした構造モデ ル上構造定数の決め方を検討したい.

リブ構造編布の基本的構造は $1 \times 1$ リブ構造で，ついで アウトウエアとしても最近広く用いられるようになった 両面組織をむつインターロック編布であるが，この $2 つ$ の組織の編布の構造モデルとその設定方法を提出する.

従来から， $1 \times 1$ リブ編布の構造に関しては，J.A.

Smirfitt ${ }^{4)}$ が G.A.V. Leaf ${ }^{5 !}$ の平編の構造モデルを少し 変更したリブ構造モデルを採用して伸長特性の解析を試 み，単純エラスチカに基づいて弓張特性を計算している が，ループ長 $l$ 上系直徐 $d$ の比 $l / d=21.0$ の上きのみ 戦密に適用し得るようなモデルであって，この条件下で しかもコース方问の一軸伸長の，それもきわわて初期の 伸長特性しか計算できない6?

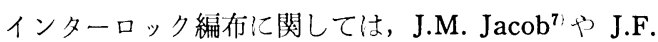
Knapton $^{81}$ ，D.L. Munden ら ${ }^{9}$ によって変形前の構造 の寸法が経験式圭主にして研究さ机ている以外はほ上ん ど研究がなされていない。こして, 構造の詳細に関して P. Grosberg ${ }^{10}$ は G.A.V. Leaf の平編の構造モデルな どを用いて，きわめて簡単なモデルを提出しているにす ぎない。

これらはいずれす寸法的な性質を検討するためのもの であり，伸辰特性の解析に適用する にはあまりにす現実の構造からかけ 離れている.さらに杀の曲がり形状 をエラスチカの理論によって决めて いるが，この形状はかなり複雑な形 状となり，その弓張特性の解析をき わめて煩雑化することが予想され る. 本研究におけるモデル設定の目 的は，一軸，二軸伸長特性の計算が そのモデルを用いて直ちに実行する ことができ，かつ幾何学的構造をで きるだけ忠実に表現し得るようなモ デルを決めることにある.

\section{2. 構造理論}

$2.11 \times 1$ リブ編布の単位構造上構造定数

第 1 図はリブ構造をむつ編布の基本組織である $1 \times 1$ リブ編布構造在糸の中心線で示したもので, 表目のウエ

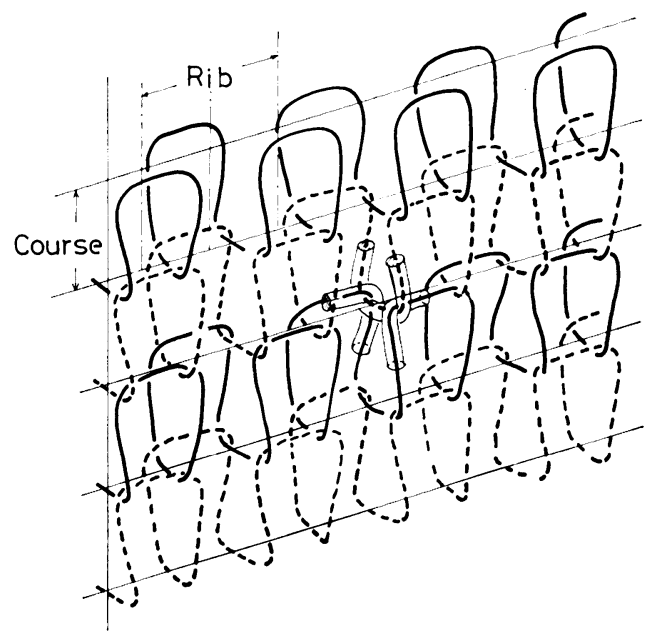

（第 1 困） $1 \times 1$ リブ編布の構造

ール上罢目のウエールが交互に並んでいる. その単位構 造は四中で糸に太さを与えて示した部分で，これの繰り 返しで編組織が形成される. 第 2 図にこの単位構造のみ 走示している.

リブ構造をもつ編布は平編構造を基淮としているが， $1 \times 1$ リブ編布では眓のように平編布の表目が表甚に現わ れる構造で，表寒在連結する糸が存在する。

いま, 直交座標軸 $\mathrm{X}_{1}, \mathrm{X}_{2}, \mathrm{X}_{3}$ を設定し, $\mathrm{X}_{1}$ はウエ 一ル， $\mathrm{X}_{2}$ はコース方向に， $\mathrm{X}_{3}$ は厚み方向にとる. $\mathrm{X}_{2}$ $\mathrm{X}_{3}$ 面は第 2 四(b)に示严表表結ぶ采が表目（罒で手前 の面在表とする）の禾との接触在終える接触分離点在含 むようにより，乙の面が図で上方へ向かう表目ウエール の杀を切ってできる杀断面の中心を原点にとり， $\mathrm{X}_{1}, \mathrm{X}_{2}$, $\mathrm{X}_{3}$ 軸を図のように定める.

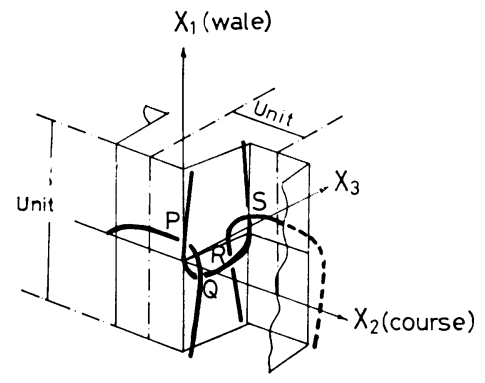

(a) Unit Model

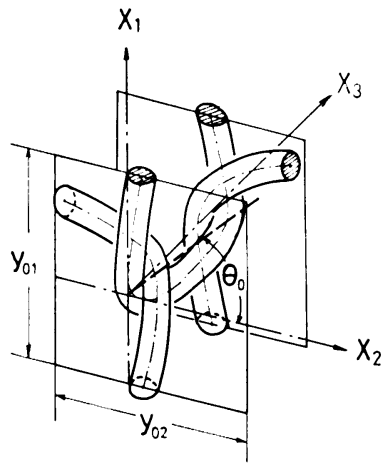

(b) Unit Structure

（第 2 図） $1 \times 1$ リブ編布の単位構造 


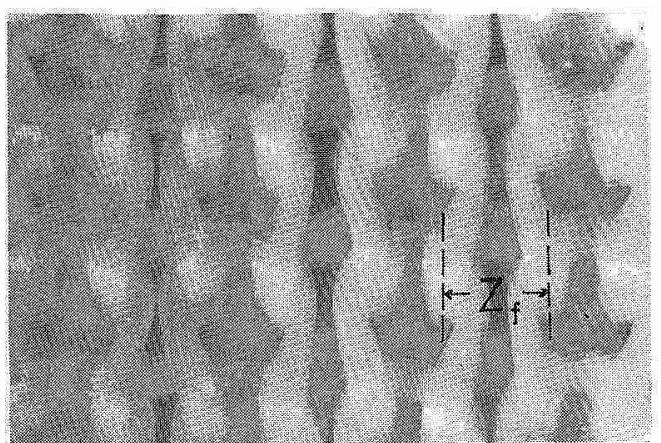

(a) 表 面

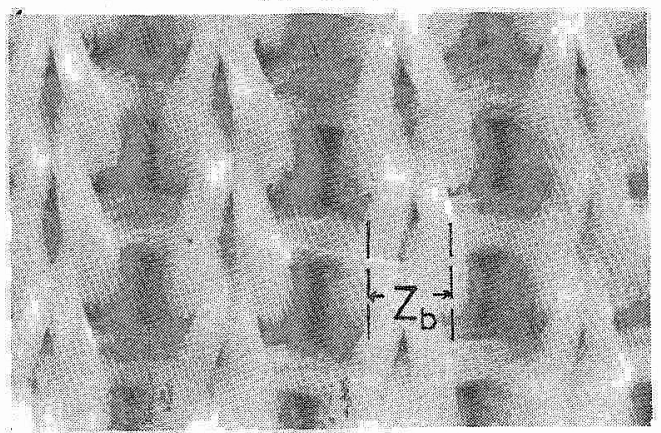

(b) 裹 面

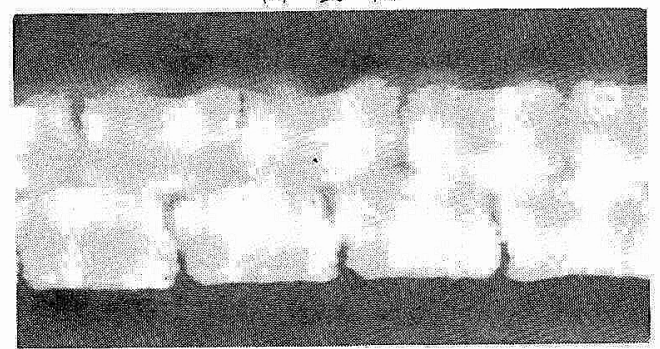

(c) コースう间にそった绦面

(第 3 図) $1 \times 1$ リブ編有ゆ形状

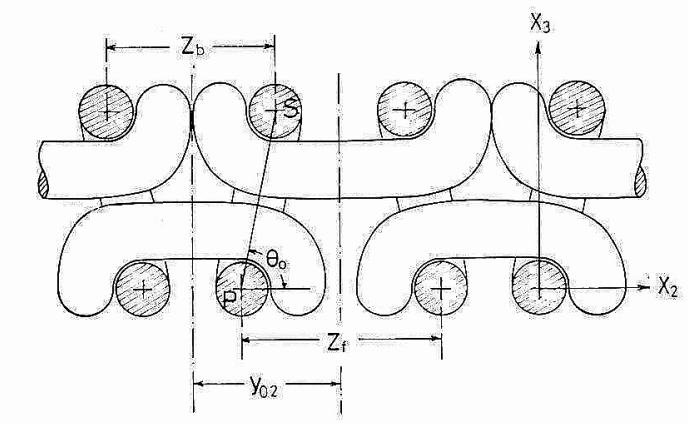

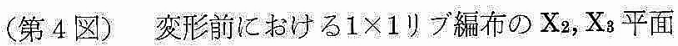

第 4 図は $\mathrm{X}_{2} \mathrm{X}_{3}$ 平量で切ら机る組織の断面で, 図示の

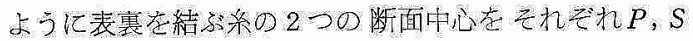
よする.

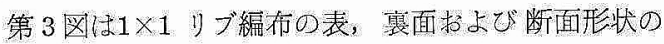
写真である.
構造定数は次のようたなる。

$y_{01}$; ウエール力问の単位構造長さ

$y_{02} ;$ ヨース方向の単位棈浩長さ

$L$; 単位構造中の杀の長さ

\section{$D ;$;}

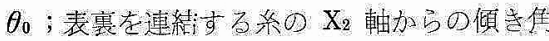
ど机ら構造定数は钼測量から炏式厄計算或る.

$$
\begin{aligned}
& y_{01}=\frac{1}{C} \\
& y_{02}=\frac{1}{2 R} \\
& L:=\frac{G}{2 R C Y}
\end{aligned}
$$

ここだ,

$C$; 単位長さ $(\mathrm{cm})$ 当

$R$; 单位長さ $(\mathrm{cm})$ 当た 500 少 ブ数

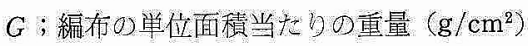

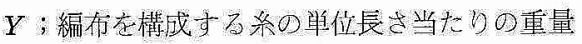
$(\mathrm{g} / \mathrm{cm})$

系の太さは䋐維が六角形最密充てれ し した之きの長

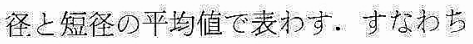

$$
\begin{aligned}
& D=\frac{D_{C L}+D_{C S}}{2} \\
& D_{C L}=\frac{d \sqrt{12 N-3}}{3} \\
& D_{C S}=D_{C L} \cos 30^{\circ}
\end{aligned}
$$

ここで,

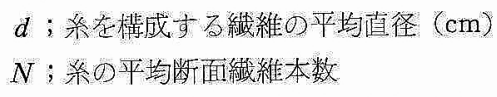

饮に $\theta_{0}$ の決定法は，後述する境界伸辰時の構造モデ 心に従い次式厄決まる。

$$
\theta_{0}=\tan ^{-1}\left(\frac{2 \sqrt{(h D)^{2}+(3 D)^{2}-\frac{1}{4}\left(Z_{f}+Z_{b}-2 y_{02}\right)^{2}}}{Z_{f}+Z_{b}-2 y_{02}}\right)
$$

ここで

$$
Z_{f} \text {; 表編目間隔（第 } 3,4 \text { 図参照） }
$$

$Z_{b} ;$; 寒編目間隔（第 3,4 図参照）

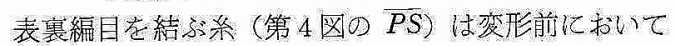

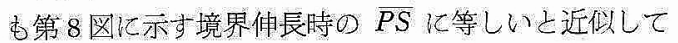

$$
\begin{aligned}
& \overline{P S}=\sqrt{(h D)^{2}+(3 D)^{2}} \\
& h=\frac{\pi}{2 \sqrt{2}}
\end{aligned}
$$

ここで

$h$; 杀の交差部分の $\mathrm{X}_{1}$ 扮よび $\mathrm{X}_{2}$ 軸上への投影辰 さで，平編有の場合の $h$ と同じ值をとる.

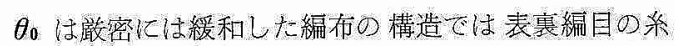
の田げカと，表褧編目在結ぶ条のねじり才が鈎合った構 遗加ら定まり，仕上加工工程によって $\theta_{0}$ は変化すると 


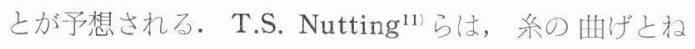
じり剛性が緩和された編日の形状を支配するととを示し ているが，この方法圭適用して $\theta_{0}$ 老定めるにはあまり にあ煩雑で現実性に之しい, したがって, 本理論では編 布の観測できる寸法から近似的に(7)式で推定する方法存 とった.

\section{2 構造モデル設定の条件}

第 3 図のように変形前の曲がった杀が，第 5 网のよう にウエールとコース方向にそって二軸伸長したとき, 系 は伸長せずに曲げが伸ばされる变形を考える。すな拈ち 単位構造を構成する系の長さ $L$ は一定值在保持したまま 禾の交差部分を除いてまっすぐに伸びきる変形で，この

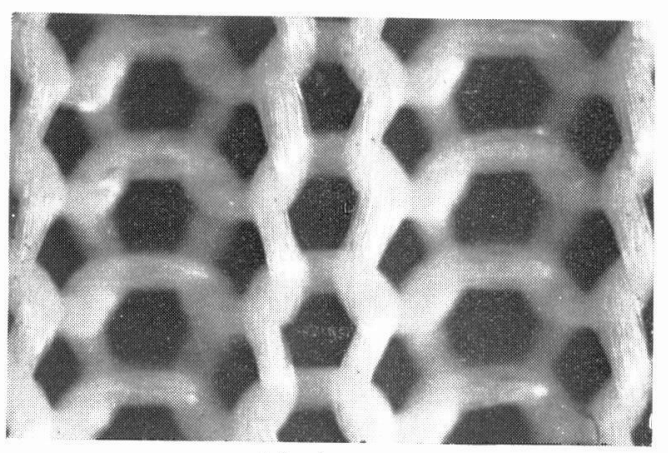

(a) $k_{1}=0$

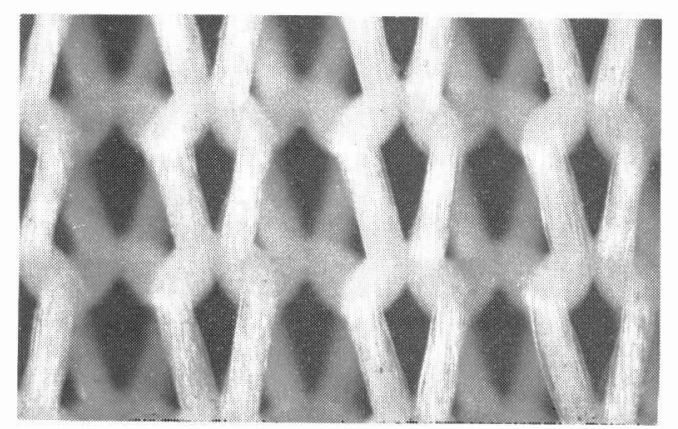

(b) $k_{1}=k_{2}=1$

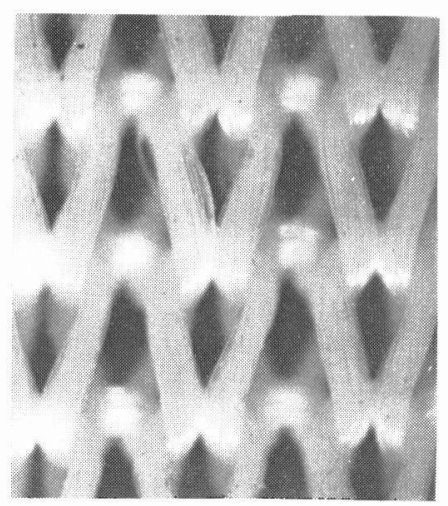

(c) $k_{2}=0$

（第 5 図） $1 \times 1$ リブ編布の境界伸長状態
伸びきる状態を境界伸長状態と定義 ${ }^{12)}$ し, その立体的幾 何学形状に忠実な構造モデルを設定するが，このモデル

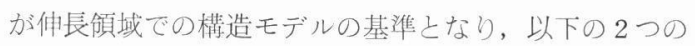
モデルがこれより導か机る。まず，この状態を境にして それ以上の伸長では，糸の伸長が主に寄与するが，この 領域, すなおち糸伸長効果領域の構造モデルと, 次に杀 の伸びが寄与せず曲げやねじりの効果が主になる曲げ効 果領域での構造モデルを定める. すでに報告したように この 2 つの構造モデルが定まると，それらからそれぞれ の領域での引張特性が独立に計算され, その両者を重小 合わせて編布の引張特性を計算する方法をとる ${ }^{1,3)}$. ま たモデルはすでに平編布の研究で行なったようにツ孤之 まっすぐ棒の組み合わせで組み立てる方法在とる11.

第 2 図の単位構造考 $\mathrm{X}_{1}$ 軸， $\mathrm{X}_{2}$ 軸の各方向にそ机ぞ 机任意の伸長比 $\lambda_{1} ， \lambda_{2}$ を与えて伸長するとき, 前述の 2つの伸長過程では, 次のような变形が行な执る.

曲げ効果領域：まず，第 3 図にみられる $\mathrm{X}_{2}$ 軸方问の 杀の曲がりが伸びると同時に表面之空面の編目を結ぶリ ンクの糸が $\mathrm{X}_{2}, \mathrm{X}_{3}$ 面内で回転して $\mathrm{X}_{3}$ 軸となす佣度 $\theta$ を增加させ, 編仍が伸長して境界伸長比に達する過程, この伸長過程ではリンクの糸の回転で杀に稀じれが生じ て，乙机も伸長に対する抵抗力となる。

伸長効果領域：第 5 四のように境界伸長状態に達した あとの, 境界伸長以上の仲長によって, 禾の伸長がはじ まり, 系の張力, 杀間の摩擦力, 杀の圧縮力によって伸 長荷重が支配される過程.

これらの過程での伸長特性の計算に用いる構造モデル は境界伸長状態において聥続的に連結されねばならな い.これが第1の条件である. そのために, 変形前の構 造モデルは境界伸長比の上きにこの境界伸長状態を上る ようなモデルであることが必要条件になる。第 2 にそれ ぞれのモデルは，前記 2 つの過程を正確に表現するよう なモデルでなけ机ばならない. 第 3 に, これらモデルの 構造定数は実際の編布の構造定数から簡単に決定できる、 ことが必要である。

\section{2. $31 \times 1$ リブ編布の構造モデル}

2.3 .1 境界伸長状態の構造モデル

第 2 図の単位構造において, ウエールとコース方に そって二軸伸長を与えるとき, その変形様式, すなわち 二方向の伸長比の遠いによって境界伸長状態の幾何学的 形状は第 5 図のように異なる。

この境界伸長状態の構造は，以下に述べるように曲げ 効果领域や伸長効果領域の構造モデル在決める基淮構造 であるから，その决め力は精密さが要求さ机る。

まず，二軸変形様式在次のように定義される $k_{i}$ によ つて表現する ${ }^{22}$. すなわち， $\mathrm{X}_{1} ， \mathrm{X}_{2}$ 軸力向の伸長ひず み在卡机ぞ机 $\varepsilon_{1} ＼varepsilon_{2}$ とし， 


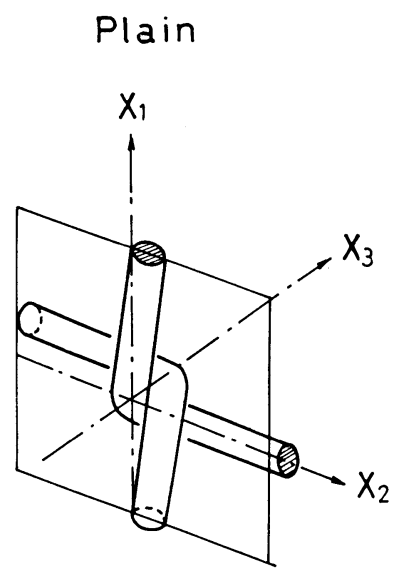

(a)
$1 \times 1$ Rib structure

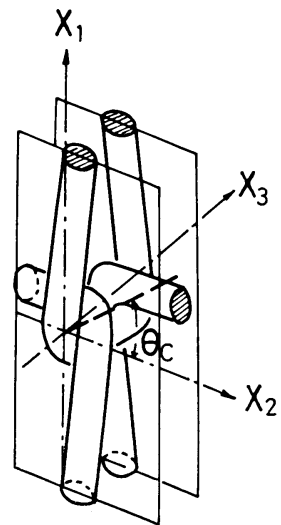

$$
\left(k_{2}=\varepsilon_{2} / \varepsilon_{1}=0\right)
$$

(b)

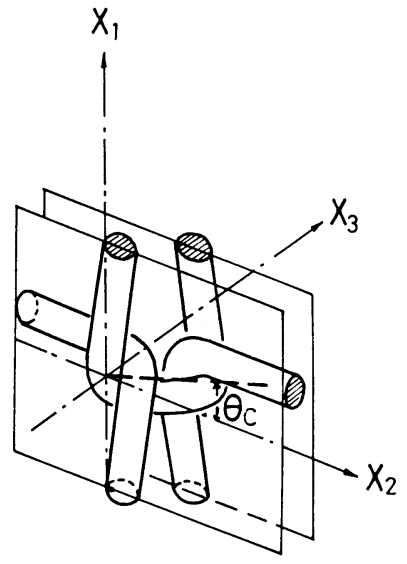

$\left(k_{1}=\varepsilon_{1} / \varepsilon_{2}=0\right)$

(c)

（第 6 図）平編布と $1 \times 1$ リブ編布の境界伸長状態

$$
\begin{aligned}
& k_{1} \equiv \frac{\varepsilon_{1}}{\varepsilon_{2}}=\frac{\lambda_{1}-1}{\lambda_{2}-1}, \quad \varepsilon_{1}<\varepsilon_{2} \text { のとき }
\end{aligned}
$$

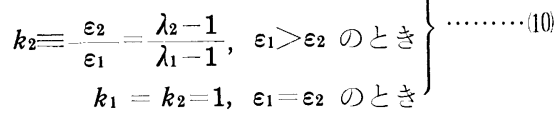

第 6 図( $(\mathbf{a})$ に示すように, 平編構造ではその境界伸長状 態は变形様式によらず，一定の杀の交差形状をとるが， $1 \times 1$ リブ構造では同四(b)，(c)のように変形様式に依存与 万.

両者を比較するため，それぞれについて境界伸長時に

Plain

$1 \times 1$ Rib Structure
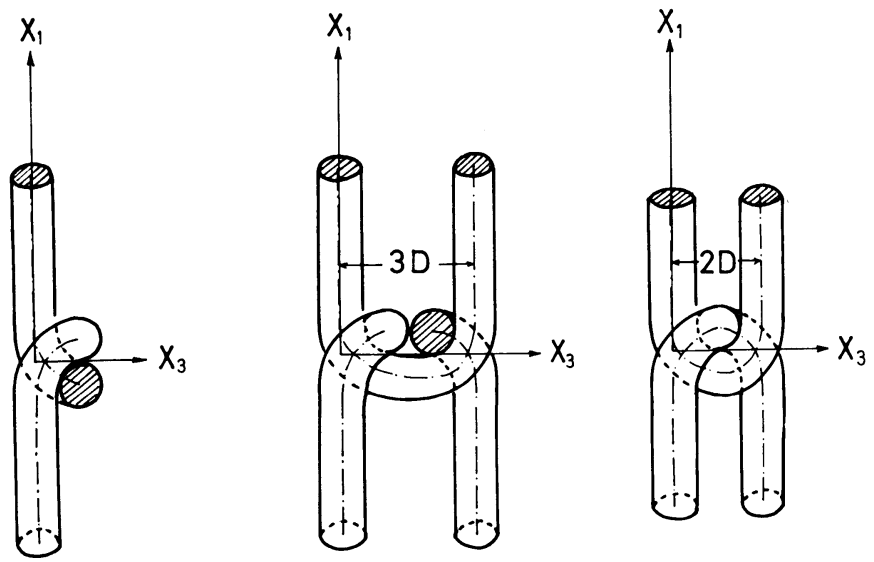

$$
\left(k_{2}=\varepsilon_{2} / \varepsilon_{1}=0\right) \quad\left(k_{1}=\varepsilon_{1} / \varepsilon_{2}=0\right)
$$

（第 7 図）平編布上 $1 \times 1$ リブ編布の境界伸长状態における $\mathrm{X}_{1}$, $\mathrm{X}_{3}$ 平面での形状
おける $\mathrm{X}_{1} ， \mathrm{X}_{3}$ 平面で切った断面形状を第 7 図に， $\mathrm{X}_{2}$, $\mathrm{X}_{3}$ 平面でのそ机を第 8 四に示す.

$1 \times 1$ リブ構造では $k_{i}$ によって表亭編目を結ぶ糸 $P S$ と $\mathrm{X}_{2}$ 軸とのなす角度 $\theta$ が暴なり，したがって交差部尔 での采が互に巻きつく長さや，表編目から離机て亭編目 へわたるリンクの長さ $\overrightarrow{Q R}$ はこの角度 $\theta$ によて変化 する.

ここで糸の直径 $D$ で規格化して,

糹の巻きつき長さ $=c D$

$$
\overline{Q R}=e D
$$

上して, $c, e$ 在次の上うに近以的に决 める。

いま, 変形様式 $k_{i}$ での境界伸長時の $\theta$ の值を $\theta_{c}\left(k_{i}\right)$ 亡する之，第 $7 ， 8$ 四 に示すように $\theta_{c}\left(k_{1}=0\right), \theta_{c}\left(k_{2}=0\right)$ は 第 8 図の境界伸長時の $\overline{P S}$ が $k_{i}$ 亿関せ ず $k_{2}=0$ の上きの值（(8)式で表わされ る）に等しい上仮定して，第 7,8罒の 単位構造の立体的幾何学形態より

$$
\begin{aligned}
& \theta_{c}\left(k_{2}=0\right)=\tan ^{-1}\left(\frac{3}{h}\right) \cdots \cdots \cdots(13) \\
& \theta_{c}\left(k_{1}=0\right)=\sin ^{-1}\left(\frac{2}{\sqrt{h^{2}+3^{2}}}\right)
\end{aligned}
$$

$\theta_{c}\left(k_{2}=0\right)$ における $S$ 点の $\mathrm{X}_{2}$ 軸八の投影 を $S_{2}{ }^{\prime}$, 同じく $\theta_{c}\left(k_{1}=0\right)$ におけるをれ を $S_{1^{\prime}}$ として，その中間の $\theta$ 值は， $S_{2}{ }^{\prime}$ $-S_{1^{\prime}}$ を第 9 四のように $k_{i}$ 值て配分し 
$1 \times 1$ Rib
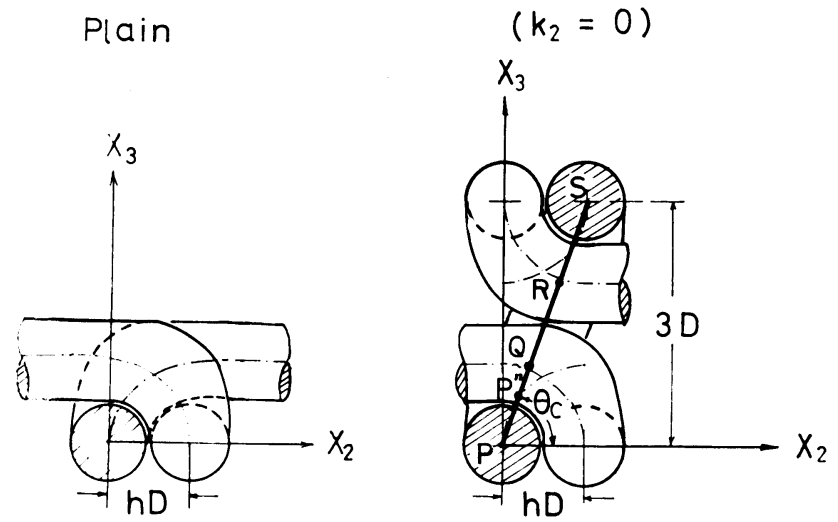

$$
\left(k_{1}=0\right)
$$

（第 8 网）平編布上 $1 \times 1$ リブ編布の境界伸長状態における $\mathrm{X}_{2}, \mathrm{X}_{3}$ 平面での形状

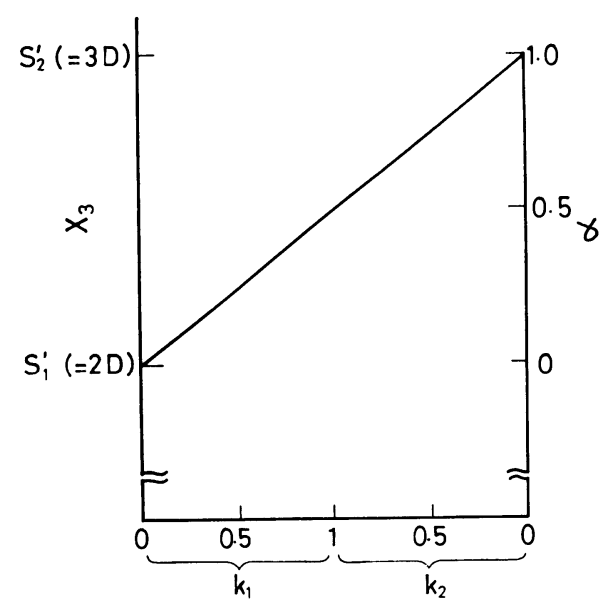

(第 9 四) $1 \times 1$ リブ編布に拈ける $k_{i}$ と $\alpha$ との関係 て $\theta$ 值を与える.

任意の $k_{i}$ においては

$$
S^{\prime}=S_{1}{ }^{\prime}+\left(S_{2}{ }^{\prime}-S_{1}{ }^{\prime}\right) \alpha_{i}
$$

ただし

$$
\left.\begin{array}{ll}
\alpha_{1}=\frac{k_{1}}{2}, & \left(\varepsilon_{1}<\varepsilon_{2}\right) \\
\alpha_{2}=1-\frac{k_{2}}{2}, & \left(\varepsilon_{1}>\varepsilon_{2}\right) \\
\alpha_{1}=\alpha_{2}=\frac{1}{2}, & \left(\varepsilon_{1}=\varepsilon_{2}\right)
\end{array}\right\}
$$

以上をまとめて $i=1,2$ に対し

$$
\begin{aligned}
\theta_{c}\left(k_{i}\right) & =\sin ^{-1}\left\{\alpha_{i} \sin \left(\theta_{c}\left(k_{2}=0\right)\right)\right. \\
& \left.+\sin \left[\left(\theta_{c}\left(k_{1}=0\right)\right)\left(1-\alpha_{i}\right)\right]\right\}
\end{aligned}
$$

(17)式より $\theta_{c}$ と $k_{i}$ との関係を求めて第10図行示与.

次に，cおよび $e$ はいずれも上述の $\theta_{c}\left(k_{i}\right)$ の関数々 して以下のように定まる.

平編構造の交差部における糸の巻きつき形状は，第 11 図のように $p$ から $q$ 一直径 $D$ のらせん状に巻きつくモデ ルをすでに採用している゙が， $1 \times 1$ リブ編布では，上記

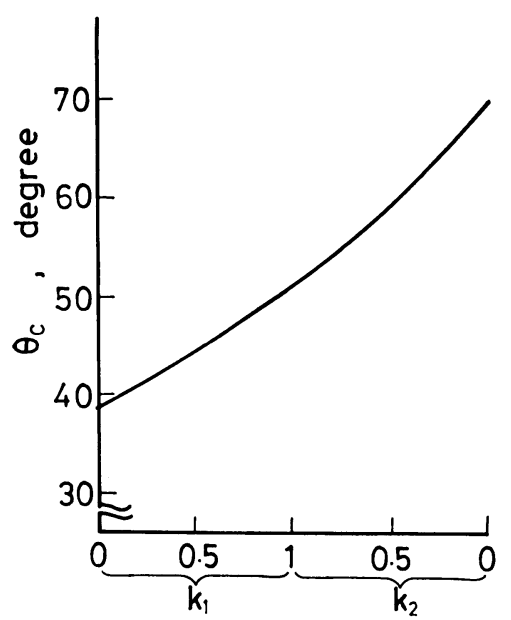

(第10羽) $1 \times 1$ リブ編布における $\theta_{c}$ 上 $k_{i}$ この関係

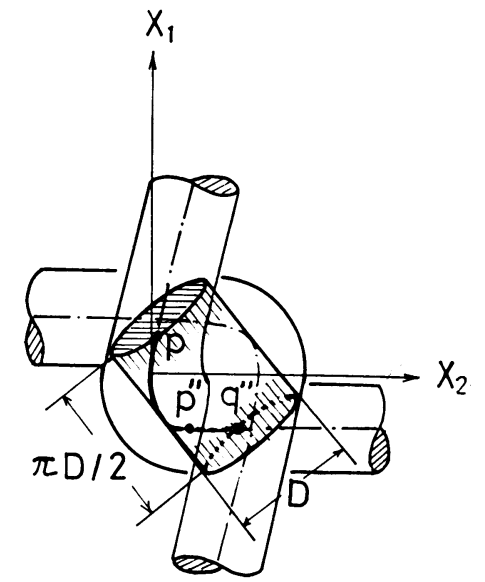

（第11四）平編構造の交差部における杀の巻きつき形状 平編型の卷きつきから直佳 $2 D$ の四管巻きつきへ移行 し, 巻きつきの 2 つの型が混在する. コース方向への变 
形がウエール力向より大きい変形様式では平編型の部分 が多く, ウエール方向の伸長比が大きい変形様式では後 者の巻きつき型が主になる，前者の平編型巻きつきを第 一種, 後者の $2 D$ 冈管巻きつき型を第二種の卷きつき型 上する。

この第一種から第二種への移行点（第12眓 $\mathrm{P}^{\prime \prime}$ 点）を 求めるのに次に示す方法をとる.

第12四に示す $P S$ 間の杀の中心線在 $\mathrm{X}_{2}, \mathrm{X}_{3}$ 平面へ 投影し，P点から発した糸が最初に $P S$ 在結ぶ直線 $\bar{P} \bar{S}$

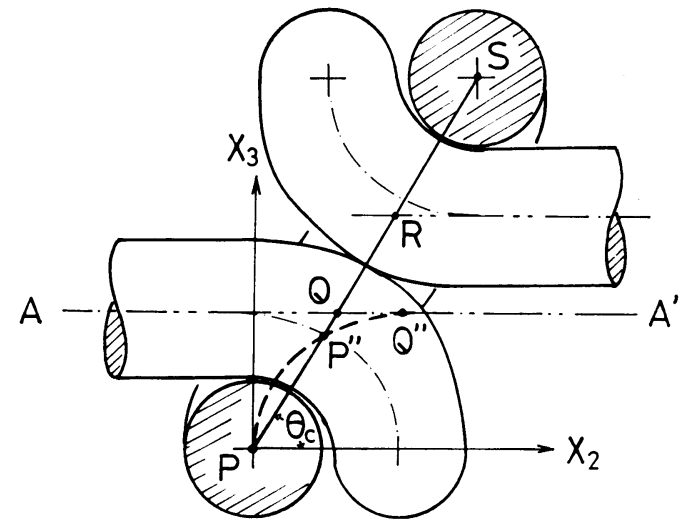

（第12戝） $1 \times 1$ リブ構造の $\mathrm{X}_{2}, \mathrm{X}_{3}$ 平面での采 の巻きつき形状

上交万点 $P^{\prime \prime}$ までは第11四に示す第一種巻きつき形状 在上り, その長さを $c_{1} D$ とする. 次に点 $P^{\prime \prime}$ 加ら $Q$ 点までは直径 $2 D$ の真直四管へ入射角 $\gamma$, 巻きつき角 $\pi / 2$ の第二種型で巻きつく. この部分の巻きつき長さを $c_{2} D$ 亡する. すなおち $c D=\overparen{P P^{\prime \prime}}+\overparen{P^{\prime \prime} Q}$ である. $P^{\prime \prime}$ 点在求める計算法は次のような方法がある.

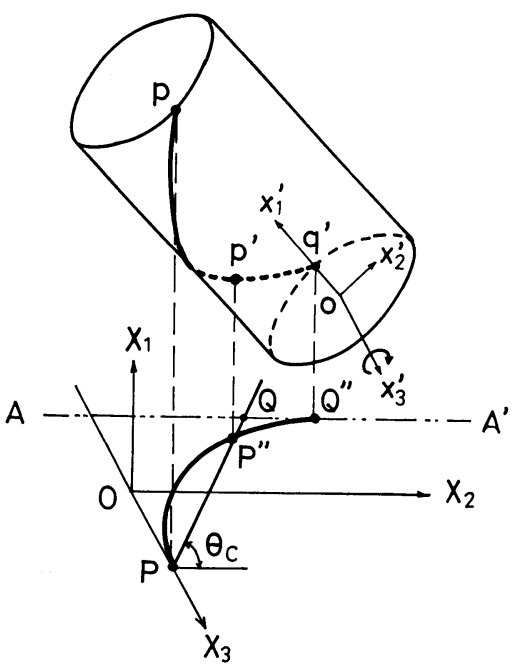

（第13図）杀の巻きつき進入位置 $\mathrm{P}^{\prime \prime}$ 点 (X座標系は第 2 罒の座標系とは異なる)
第11四のように第一種巻きつきでは, 杀の中心線は直 栙Dのスパイラルで，またスパイラルの 1 ピッチの進み は $\pi D$ である. その軸は $\mathrm{X}_{1}, \mathrm{X}_{2}, \mathrm{X}_{3}$ 軸に対し, それ ぞれ $45^{\circ}, 45^{\circ}, 90^{\circ}$ 傾いている.

いま, このスパイラルの $\mathrm{X}_{2}, \mathrm{X}_{3}$ 平面への投影を求め るため, スパイラルの中心軸を $\mathrm{x}_{1}$ 軸, $\mathrm{X}_{3}$ 軸に平行に $\mathrm{x}_{3}$ 軸, $\mathrm{X}_{2}$ 軸加ら $45^{\circ}$ 回転して $\mathrm{x}_{2}$ 軸をとる. (第 13 汹)

$x_{i}$ 系ではスパイラルの式は

$$
\left.\begin{array}{l}
x_{1}=\frac{D}{2} t \\
x_{2}=\frac{D}{2} \sin t \\
x_{3}=\frac{D}{2} \cos t
\end{array}\right\} 0<t<\pi
$$

(18)式を(19)式により $X_{i}$ 系へ座標变換して $\mathrm{X}_{2}$ と $\mathrm{X}_{3}$ の 関係を求めると，第14汹の $\mathrm{X}_{2}, \mathrm{X}_{3}$ 平面曲線上へのスパ イラルの投影が得られる.

$$
X_{i}=\sum_{j=1}^{3} a_{j i} x_{j}(i=2,3)
$$

ただし

$$
a_{i j}=\cos \left(x_{i}, X_{j}\right)
$$

この曲線と $\mathrm{X}_{2}$ 軸から角度 $\theta_{c}$ 傾いた $\overline{P S}$ との交点 $P^{\prime \prime}$ は第14㕳のように求まる. $P$ 点と $P^{\prime \prime}$ 点間の条の

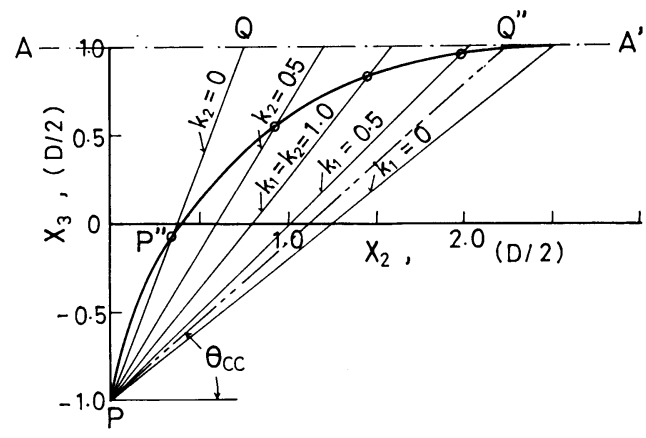

（第14図）平編型巻きつきの $\mathrm{X}_{2}, \mathrm{X}_{3}$ 平面への軌跡

長さを求めるには $x_{i}$ 座標系が容易であるから， $P^{\prime \prime}$ 点 の座標 $\left(\mathrm{X}_{1}, \mathrm{X}_{2}, \mathrm{X}_{3}\right)$ を再び(21)式で旧座標系へ変換して $P^{\prime \prime}$ に対応する $p^{\prime}$ 点 (第13図) が決まる.

$$
x_{i}=\sum_{j=1}^{3} a_{i j} X_{j}
$$

$p^{\prime}$ 点にお汀る $x_{1}$ 座標 $\left[x_{1}\right]_{p^{\prime}}$ より, 第一種の巻きつ き長さ $p p^{\prime}\left(=c_{1} D\right)$ が次式で求まる.

$$
c_{1}=\frac{\sqrt{2}}{D}\left[x_{1}\right]_{p^{\prime}}
$$

次に，第二種の巻きつきは，第12図にもどり， $p^{\prime}$ 点 に対忍する $P^{\prime \prime}$ 点より始まり，杀が巻きつきを離れ， 直線部分 $Q R$ 八移る $Q$ 点まで前述の第二種の巻きつき 在行なう． $Q$ 点は線 $A A^{\prime}$ と線 $P S$ との交点であるか 
ら変形様式 $k_{i}$ によって $A A^{\prime}$ 線上を移動し， $Q^{\prime \prime}$ 点は $P^{\prime \prime}$ と $Q$ 点が一致する場合はすべて第 1 種巻きつきにな る. この場合の $\theta_{c}$ の值を $\theta_{c c}$ と定義する. したがって $\theta_{c c}$ は次式で表わされ，完全に第一種の巻きつき形状を とって表編目から寒編目へ糸が移行する場合の $\theta_{c}$ の境 界値である。

$$
\theta_{c c}=\tan ^{-1}\left(\frac{1}{h}\right) \div 42^{\circ}
$$

巻きつき終了点 $Q$ は, $\theta_{c}>\theta_{c c}$ のときは第12眓のよう に, 線 $P S$ と $\mathrm{X}_{2}$ 軸にそう表編目の糸の中心線 $A A^{\prime}$ 之 が交差する点をとる. また， $\theta_{c}<\theta_{c c}$ のときは $\theta_{c}=\theta_{c c}$ の ときの終了点 $Q^{\prime \prime}$ に固定されるものとする.

$P$ 点から $Q$ 点まで, すべて第二種の卷きつきをすると きは，第14図の直線 $P Q$ がその投影で，乙のときの巻 きつき角は $90^{\circ}$ である.

ここで，第二種への移行時の入射角 $\gamma は \theta_{c}$ の関数で あり， $\theta_{c}$ はすでに(17)式で与えられるように変形様式 $k_{i}$ により定まる。

$Q$ 点における $\mathrm{X}_{2}$ 座標を $\left[\mathrm{X}_{2}\right]_{Q}$ として

$$
\tan \gamma=\frac{\left[X_{2}\right]_{Q}}{\frac{\pi D}{2}}
$$

または次の関係を利用して求める方法もある.

$$
\left[X_{2}\right]_{Q}=D \tan \left[\frac{\pi}{2}-\theta_{c}\left(k_{i}\right)\right]
$$

(24)式に(25)式を代入して

$$
\gamma=\tan ^{-1}\left\{\frac{2}{\pi} \tan \left[\frac{\pi}{2}-\theta_{c}\left(k_{i}\right)\right]\right\}
$$

次に，第二種巻きつきの $P^{\prime \prime} Q$ 点間の巻きつき長さ $c_{2} D$ は, $P^{\prime \prime}, Q$ 点の $\mathrm{X}_{2}$ 座標 $\left[X_{2}\right] p /, \quad\left[X_{2}\right] Q$ より

$$
c_{2} D=\frac{\pi D}{2}-\frac{1}{\cos \gamma}\left(1-\frac{\left[X_{2}\right]_{p \prime \prime}}{\left[X_{2}\right]_{Q}}\right) \cdots \cdots \cdots(27)
$$

(27)式に(24)式を代入して

$$
c_{2}=-\frac{\pi}{2} \frac{1}{\cos \gamma}-\frac{\left[X_{2}\right] p^{\prime \prime}}{D \sin \gamma}
$$

変形様式 $k_{i}$ における交差部分での杀の卷きつき長さ は(22)，(28式を用いて，

$$
c D=c_{1} D+c_{2} D
$$

以上は表編目側について計算したが，表編目にも同じ ように巻きついている. すなわち， $P$ 点が $S$ 点に， $Q$ 点 が $R$ 点に対応する.

一方，第12四で表寒編目を結ぶ杀が表編目との交差を 離れて裹編目之の交点に至る間すなわち $\overline{Q R}$ は, 境界 伸長状態であるからまっすぐに糸がわたる， $\overline{P S}$ は変形 様式に関せず(8)式で表わされるので， $\theta_{c c}$ の定義に従っ て $\theta_{c}>\theta_{c c}$ のときの $\overline{Q R}$ は

$$
\overline{Q R}=e\left(k_{i}\right) D=\sqrt{h^{2}+3^{2} D-\frac{2 D}{\sin \theta_{c}\left(k_{i}\right)}} \cdots(30)
$$

$\theta_{c} \leqq \theta_{c c}$ のときの $\overline{Q R}$ は,

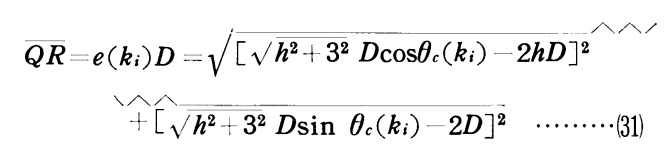

以上のように, $1 \times 1$ リブ構造では $c_{1}, c_{2}, c, e$ は $\theta_{c}$ 上一定の関係にあり，それぞれ $k_{i}$ の関数として誘導さ 机。，この関係第15四に示す.

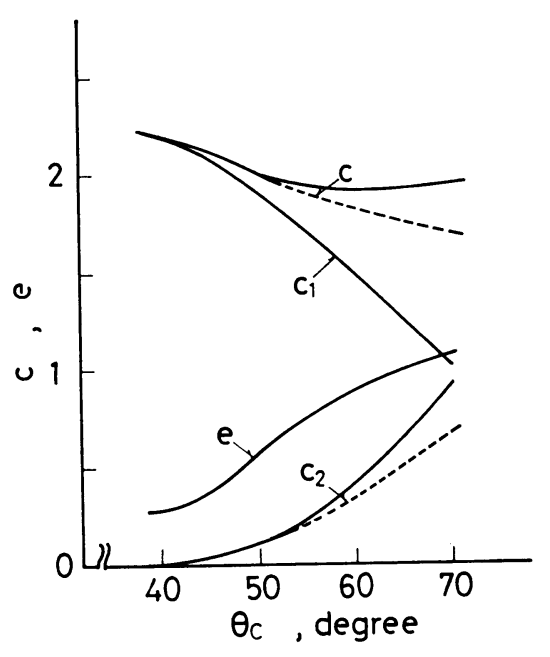

(第15図) $1 \times 1$ リブ編布における $\theta_{c}$ よ $c$ および $e$ との関係

$k_{i}$ を与えたときに $\theta_{c}$ は(17)式で，または第10図で与え られ，第15㕳上り直ちに $c_{1}, c_{2}, e$ を求め, 杀の巻きつ き長さ $c\left(k_{i}\right) \cdot D$ および表寒編目を結ぶ糸の長さ $e\left(k_{i}\right) \cdot D$ が求まる.ただし，境界伸骎時の巻きつき形状によって は杀の圧縮効果のため直径 $D$ が变化する効果を無視でき ない. 後述するように, $c_{2}(k i) \cdot D$ に関しては点線で示 した経験的な修正曲線を用いるほうが理論計算の精度は 高い.

次に，上記で計算した采の交差部およびリンクを除く 部分の采の長さを求める.

いま,

$y_{c 1}$; 境界伸長時のウエール力向の単位構造長さ

$\boldsymbol{y}_{c 2}$; 境界伸長時のコース方向の単位構造長さ

$\varphi_{c}$; ウエール方向の采之 $\mathrm{X}_{1}$ 軸とのなす角度 とする.

$\mathrm{X}_{1}$ 軸方向，すなわちウエール方向のまっすぐな杀は 4 本あるがそれらの長さを合計した全長 $l_{01}$ は境界伸長 時の立体的な幾何学形態より

$$
l_{01}=2 \sqrt{\left(y_{c 1}-h D\right)^{2}+(h D)^{2}}
$$

また

$$
\varphi_{c}=\tan ^{-1}\left(\frac{h D}{y_{c 1}-h D}\right)
$$

同様に, $\mathrm{X}_{2}$ 軸方向の禾長 $l_{02}$ は 


$$
l_{02}=y_{c 2}-\sqrt{h^{2}+3^{2}} D \cos \theta_{c}\left(k_{i}\right)
$$
..(34)

\section{3 .2 モデルから誘㸃される境界伸長比}

境界伸長状態は，定義より杀は伸びないで，杀の曲が りが伸びきった仮定の状態であるから，単位構造中の杀 長Lは変化しない，したがって，

$$
L=l_{01}: l_{02}: 4 c\left(k_{i}\right) D+e\left(k_{i}\right) D
$$

(35)式に(32), (34)在代入して,

$$
\begin{aligned}
L= & 2 \sqrt{\left(y_{c 1}-h D\right)^{2}}(h D)^{2}+y_{c 2}-\sqrt{h^{2}+3^{2}} D . \\
& \cos \theta_{c}\left(k_{i}\right)+4 c\left(k_{i}\right) D+e\left(k_{i}\right) D \cdots \cdots \cdots(36)
\end{aligned}
$$

が成立する.

一方, (10)式の $k_{i}$ の定義から, 七ット $\left(y_{c 1}, y_{c 2}\right)$ と $k_{i}$ 亡の関係は

$$
\begin{aligned}
& y_{c 1}=k_{1} y_{c 2} \frac{y_{01}}{y_{02}}+y_{01}\left(1-k_{1}\right), \quad \varepsilon_{1} \leq \varepsilon_{2} \text { のとき } \cdots(37) \\
& y_{c 2}=k_{2} y_{c 1} \frac{y_{02}}{y_{01}}+y_{02}\left(1-k_{2}\right), \quad \varepsilon_{1} \geq \varepsilon_{2} \text { のとき } \cdots(38)
\end{aligned}
$$
いま,

$\lambda_{c 1}, \lambda_{c 2}$; 任意の変形様式 $k_{i}$ 在与えたとき, 境界伸長 状態での布の $\mathrm{X}_{1}, \mathrm{X}_{2}$ 軸方向への伸長比で, これを境界 伸長比上定義する。この2つは与えられた $k_{i}$ 值によっ て1つのセットとして決まり，乙れを $\left(\lambda_{c 1}, \lambda_{c 2}\right)$ で表わ す. $\left(\lambda_{c 1}, \lambda_{c 2}\right)$ 在求めるには，(36)式上(37)式より $k_{1}$ をパ ラメーターとして $y_{c 1}, y_{c 2}$ につて解く. 同様に, (36) 式よ(38)式より $k_{2}$ 死パラメーターよして $y_{c 1}, y_{c 2}$ につい て解き，そ杞らの解より境界伸長比 $\lambda_{c 1}, \lambda_{c 2}$ は，

$$
\lambda_{c 1}=\frac{y_{c 1}}{y_{01}}, \quad \lambda_{c 2}=-\begin{aligned}
& y_{c 2} \\
& y_{02}
\end{aligned}
$$

上述の $y_{c 1}, y_{c 2}$ の解は後述するように四式解で求ま り,コンピューターによればさらに簡単に求まる。

\section{3 .3 糸の曲げ効果領域の構造モデル}

境界伸長に達するまでの曲げ効果領域に適用される構 造モデルは，2.2で述べた条件のように，境界伸長比の ときに境界伸長状態のモデルに等しくなるものでなけれ ばならない，この伸長過程では，第16図に示すように，

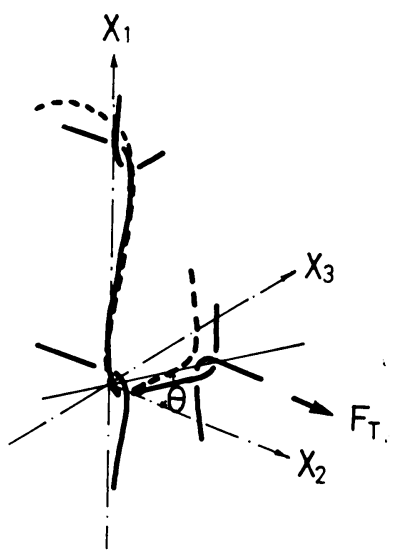

（第16戝）系の曲げ効果領域の構造モデル

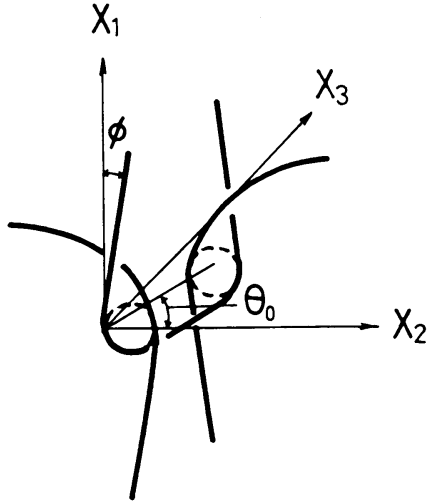

(第17図) $1 \times 1$ リブ編布の変形前の単位構造モデル

コース方向の采の曲がりが伸びると同時に表裏編目を結 ぶリンクの傾き角む $\theta_{0}$ から $\theta_{c}\left(k_{i}\right)$ まで変化する. そ してこの変形を通じて(8)式で表わされるように $\overline{P S}$ (第 8 四参照) はつ称に一定に保たれると仮定する.

まず，変形前の単位構造モデルは第17図のように円弧 上まっすぐ棒からなるモデルで単純化されている.すな わち, ウエール力问の禾は $\mathrm{X}_{1}$ 軸加ら角度 $\varphi$ 傾いている が杀はまっすぐで， $\mathrm{X}_{2}$ 軸にそう条のみが曲がっていて， この采の曲がりを在弧状曲がり細棒とする. こして，乙 の円弧の長さ $l_{0 n}$ や弦の長さ $d_{0 n}$, 凹弧の初期曲率 $K_{0}$ などは前記の条件を満たすものでなければならない。す なわち, 境界伸長比をとるとき，単位構造が境界伸長状

$$
\left(k_{1}=\varepsilon_{1} / \varepsilon_{2}=0\right)
$$
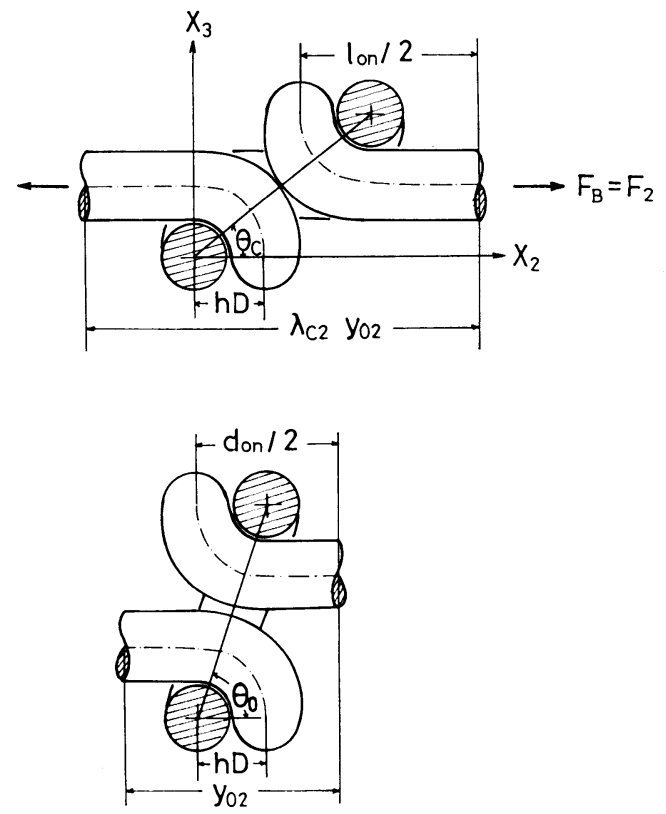

(第18忷) $1 \times 1$ リブ編布の曲げ効果領域の 基準構造モデル 
態における構造モデルに一致するように等価置換されて いなければならない。

この構造の決定のために, 平編布の場合之同様, 基淮 変形様式を $k_{1}=0$ にとる．ｌｏnは曲がりが伸びきった糸 の長さから第18図の関係を用いて，

$$
l_{0 n}=\lambda_{c 2}\left(k_{1}=0\right) y_{02}-\sqrt{ } h^{2}+3^{2} D \cos \theta_{c}\left(k_{1}=0\right)+2 h D
$$

境界伸長状態から変形前の 形状へ $l_{0 n}$ を一定にして居 し, 長さ $l_{0 n}$, 弦の長さ $d_{0 n}$ の円弧に構造を定めると き,

$$
d_{0 n}=y_{02}-\sqrt{h^{2}+3^{2}} D \cos \theta_{0}+2 h D
$$

この円弧の曲率は

$$
K_{0}=\frac{2 \theta_{0 n}}{l_{0 n}}
$$

ここで， $\theta_{0 n}$ は円弧の固定端角度で, 次式の解として求 まる。

$$
\frac{\theta_{0 n}}{\sin \theta_{0 n}}=-\frac{l_{0 n}}{d_{0 n}}
$$

この恋形前の構造から， $\lambda_{1}=1$ として $\lambda_{2}$ を增加させる とき, この币孤の曲がりは伸ばされ，その変形の計算に はエラスチカが適用される.

以上の基準变形を基化し，伸長比 $\lambda_{1}(\succ 1), \lambda_{2}$ を与 えたときのモデル構造を以下のように定める。文居 定して， $\mathrm{X}_{2}$ 軸方问の荷重を0にした上きの構造老考え る.これは依然としてモデル構造であるから, ウェール 方向の糸法まっすぐで，コース方向の系は曲がり，その 曲率は前述の $K_{\mathbf{0}}$ 上同じにする．乙のときの円孤の糸長 $l_{0}$, 弦の長さ $d_{0}$, 固定端角度 $\theta_{0}$ はいずれも $\lambda_{1}$ の関数 で基淮構造から幾何学的に以下の上うに求まる.

$$
\begin{array}{lr}
l_{0}\left(\lambda_{1}\right)=\lambda_{c 2}\left(\lambda_{1}\right) y_{02}-\sqrt{h^{2}+3^{2}} D \cos \theta_{c}\left(\lambda_{1}\right) \div 2 h D \\
\cdots \cdots \cdots(44) \\
\theta_{0}\left(\lambda_{1}\right)=\theta_{0 n} \frac{l_{0}\left(\lambda_{1}\right)}{l_{0 n}} \\
d_{0}\left(\lambda_{1}\right)=\frac{l_{0}\left(\lambda_{1}\right) \sin \theta_{0}\left(\lambda_{1}\right)}{\theta_{0}\left(\lambda_{1}\right)} & \cdots \cdots \cdots(45) \\
& \cdots \cdots \cdots(46)
\end{array}
$$

ここで, $\lambda_{c 2}\left(\lambda_{1}\right)$ は $\lambda_{1}=\lambda_{c 1}$ に対灾する $\lambda_{c 2}$ の值で, 2.3 .2 で述べた方法で求まる. この $\lambda_{1}$ 之 $\lambda_{c 2}$ の此から $k_{i}$ を 算出し，その $k_{i}$ 亿対応する $\theta_{c}$ の值，すなわち $\theta_{c}\left(\lambda_{1}\right)$ は第 9 図また泣17式で求まる. この構造モデルから， $\lambda_{2}$ を增加させるとやはり両端固定の问孤棒が伸長するモデ ル構造が得られる. そして，このモデルから $\lambda_{1}$ を固定 して， $\lambda_{2}$ 亿任意の值を与えた変形の計算が行なわれる。

\subsection{4 系伸長効果領域の構造モデル}

この領域では，杀交差の形状は境界伸長状態を保ち， 系のみが伸長する.ただし，ての伸長につれてモデル内 の各部分の糸張力の差が大きくなり滑りの条件がととの うと交差部での杀の滑りが生じる.

\section{4 インターロック編布の構造モデル}

インターロック編布の構造は第19眓に示すように, そ の単位構造は第 2 四に示した $1 \times 1$ リブ編布の単位構造を

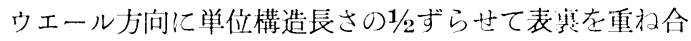
わせた二重構造モデルである。

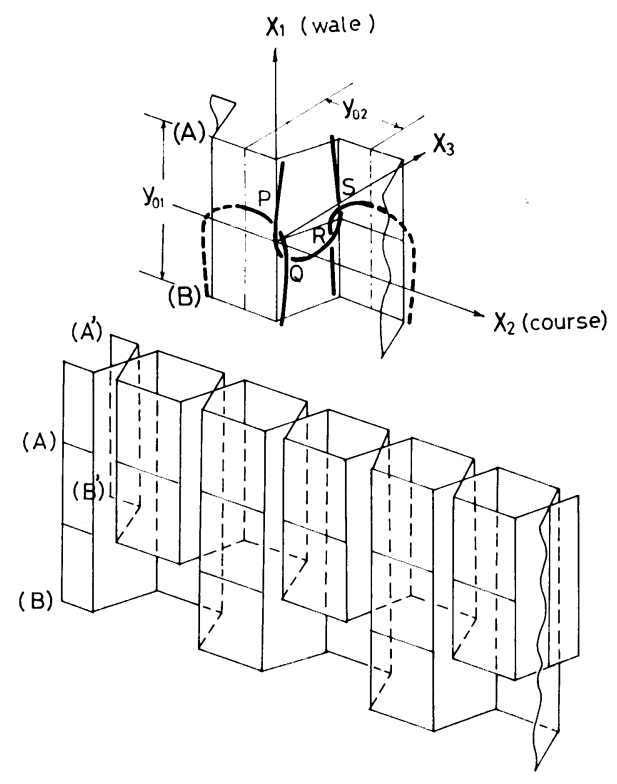

（第19眓）インターロック編布の構造

第20図はインターロック編布の表面, 寒面およびコー ス方向にそった断面形状である。この構造では第 3 㞑の $1 \times 1$ リブ構造が表目のウエールと寒目のウエールの間に さらに表目のウエール 1 つが入る。この間隔をとるため に,リブ構造がコース方向に伸長した状態のまま, 表褁 重衫合わされた二重組織になる. 力学計算には，この表 裹構造が互に十渉しないもの上仮定する. 以下の解析で は二重の組織のうちの一重のみを取り出して, $1 \times 1$ リブ 構造のモデルを単独に扱い, 単位構造モデルを設ける. ただし， $1 \times 1$ リブのそれとは若下の構造の变化がある.

構造定数 $y_{01}, y_{02}, L, D$ は単位幅当たりのウエール 数やコース数などの編布構造の観測量から計算できるこ とは $1 \times 1$ リブ編布の場合之同様である.

ただし、インターロック編布のコース方向の単位構造 長さになる $y_{02}$ は二重構造のため, ウエール数を用いて 次式によって求まる。

$$
y_{02}=\frac{1}{W}
$$

単位構造中の杀の長さ（ループ長の $1 / 2$ 亿相当する） $L$ は

$$
L=\frac{G}{2 \cdot C \cdot W \cdot Y}
$$




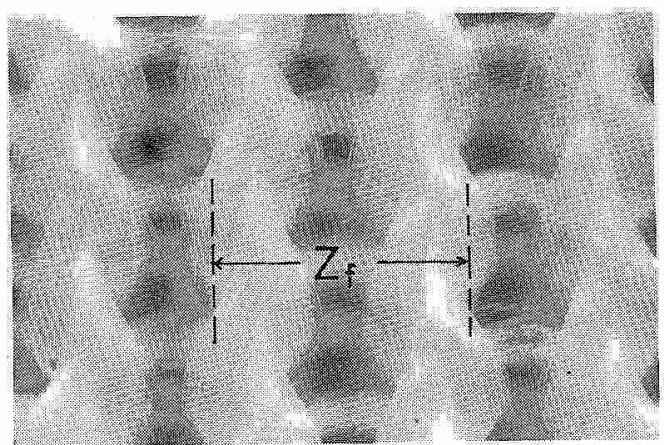

(a) 表 面

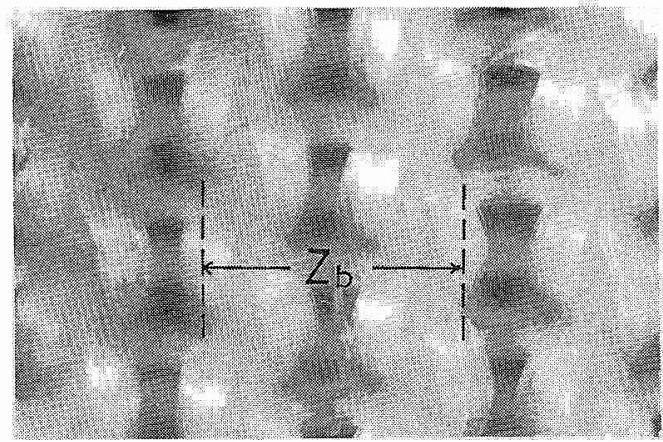

(b) 㜔 面

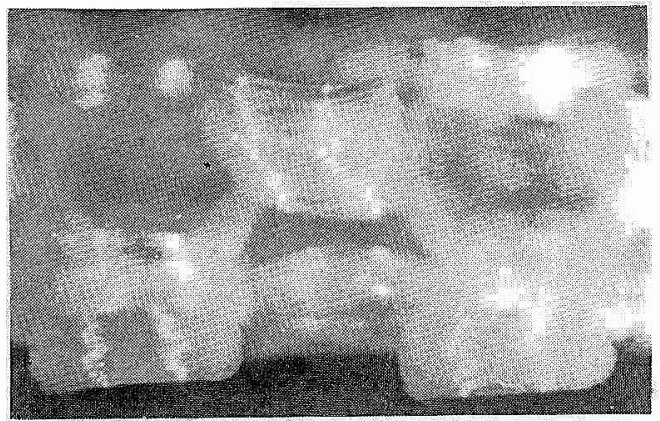

(c) コース方向にそった断面

(第20図)インターロック編布の形状

$\theta_{0}$ は第20图に示与上うに，同一コースにおいて隣接

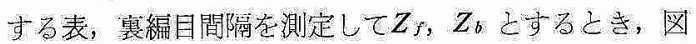
にみられるコース方向にてった䉼面に拊る表襄編目の 幾何学的猘限条件加次式定まる.

$$
\theta_{0}=\tan ^{-1}\left[\frac{3 D}{\frac{Z_{f}}{2}+\frac{Z_{t}}{2}-y_{02}}\right]
$$

$\theta_{0}$ の值は1×1リブ編布に比へてりエ一ル間隔が底がっ たたるに小さくなっている.

\section{4 .1 境界伸長状態の構造モデル}

境界伸長状態は第21図に示すように二軸恋形様式によ って異なる. 境界伸長状態の 構造 モデルは $1 \times 1$ リブ 編布の場合と同様に，この場合の基隻構造として $k_{2}=$ $0, k_{1}=0$ の变形様式下の境界伸長状態をとる.

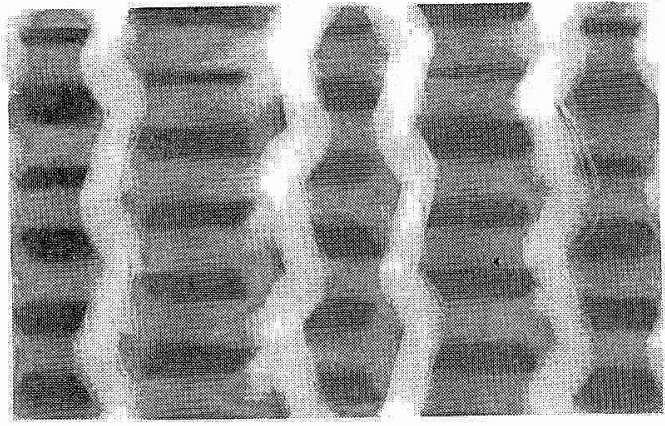

(a) $k_{1}=0$

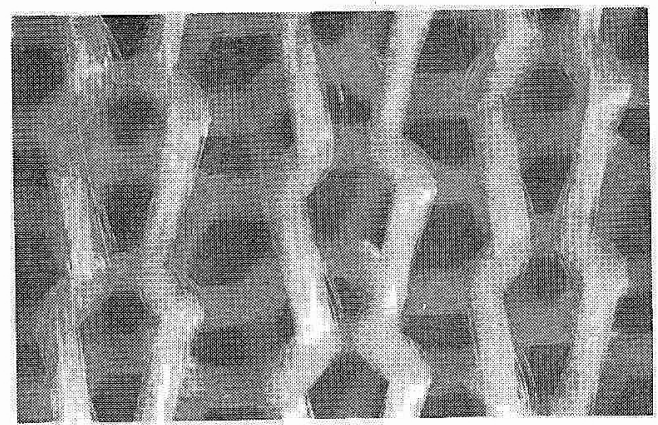

(b) $k_{1}=k_{8}=1$

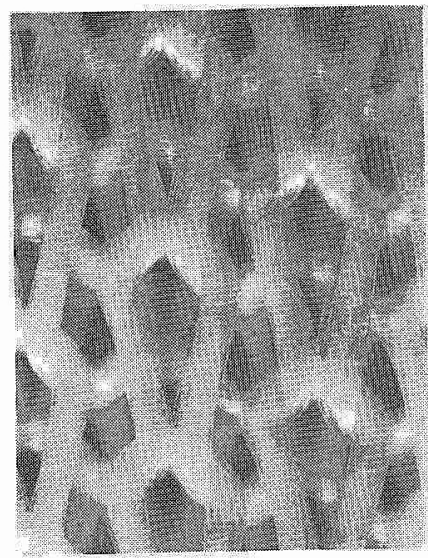

(c) $k_{2}=0$

（第21図）インターロッタ編布の境界伸長状態

境界体長状態での $\mathrm{X}_{2} ， \mathrm{X}_{3}$ 面内に拉け石幾何学的形状

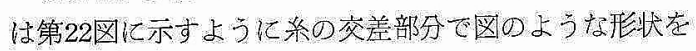

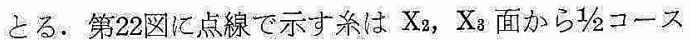
下がった平行面に存在する. $1 \times 1$ リ横造と果なる点は $1 \times 1$ 】ブ編布では第 8 网の $\overline{P S}$ が变形漛式によらず (8) 式で表わさ机る值老しる60として， $\overline{P S}$ が $\mathrm{X}_{2}$ 聀とな す角 $\theta_{c}$ を决定したのに対して，インターロック編布て は $\bar{P} \bar{S}$ か変肜様式によって変化する点にある. 図の2 つの基準となる 变北样式下での $\overline{P S}$ の $\mathrm{X}_{3}$ 軸方向への 投影長さは幾何学的に構造上の制限多ら定まる. dらて 


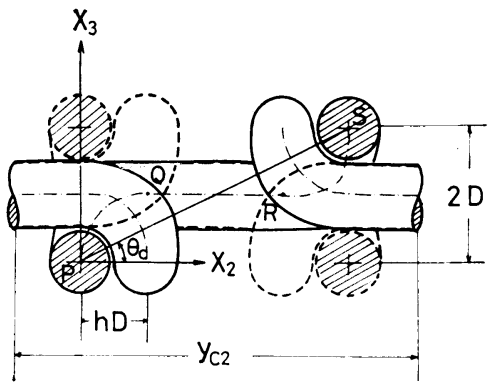

$\left(k_{1}=0\right)$

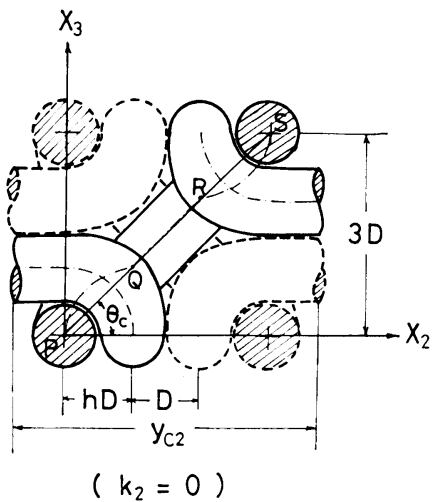

（第22図）インターロック編布の境界伸長状態における $\mathrm{X}_{2}, \mathrm{X}_{3}$ 平面での形状

境界伸長時に笚位構造がこる $\mathrm{X}_{2}$ 軸方问のウエール間隔 を図のように配分し，また変形様式 $k_{i}$ の上きの $\theta_{c}\left(k_{i}\right)$ を $1 \times 1$ リブ構造の場合之同じ方法で決定する。すなわ ち,

$$
\theta_{c}\left(k_{i}\right)=\tan ^{-1}\left[\frac{D\left(\alpha_{i}+2\right)}{\frac{y_{c 2}\left(k_{i}\right)}{2}+h D}\right] \quad \cdots \cdots \cdots(50)
$$

ただし， $\alpha_{i}$ は(16)式， $h$ は(9)式で与えられる，ここで $y_{c 2}\left(k_{i}\right)$ はまだ决まらないが，上記 $2 つ の$ 変形様式 $k_{1}=0$ 上 $k_{2}=0$ の上きは第 22 間のように構造上の拘束条件か ら幾何学的に

$$
y_{c 2}\left(k_{2}=0\right)=y_{02}
$$

この関係を(50)式に代入して $\theta_{c}\left(k_{2}=0\right)$ は求まる。最も板 端な場合であるウエール方向の一軸伸長時における $\theta_{c}$ $\left(k_{2}<0\right)$ の值は

$$
\theta_{c}\left(k_{2}<0\right)=\tan ^{-1}\left[\frac{3 D}{D(2 h+1)}\right] \div 42^{\circ} 58^{\prime} \cdots(52)
$$

この $\theta_{c}$ 值がすべての变形様式の中で最大值である.し たがって，インターロック編布構造における境界伸長時 の禾の交差形状，すなわち糸の卷きつき形状之その長さ は，平編構造における巻きつき形状をとる臨界角が前述 の(23)式で表わされる $\theta_{c c}$ でこ机が $42^{\circ}$ 在とるから，す べての変形様式に平編構造での巻きつき長さを適用する ことができる・すなわち

$$
C=\frac{\pi}{\sqrt{2}}
$$

表編目から赛編目へわたる采 $\overline{Q R}$ は，境界伸長時に はまっすぐになる。この長さ $e \cdot D$ は変形様式 $k_{i}$ の関 数之して幾何学的に次式で表わされる.

$$
e\left(k_{i}\right) D=\sqrt{\left(\frac{y_{c 2}\left(k_{i}\right)}{2}-h D\right)^{2}+\left(\alpha_{i} D\right)^{2}} \quad \cdots(54)
$$

ここで， $y_{c 2}\left(k_{i}\right)$ はまだ末知で，次のように導かれる。

采の交差部分とリンク部分を除く，ウエール方向の糸 の全長 $l_{01}$ およびコース方向の $l_{02}$ は $1 \times 1$ リブ構造にお ける場合之同様にして次式で求まる。

$$
\begin{aligned}
& l_{01}=2 \sqrt{\left(y_{c 1}\left(k_{i}\right)-h D\right)^{2}+(h D)^{2}} \\
& l_{02}=\frac{y_{c 2}\left(k_{i}\right)}{2}-h D
\end{aligned}
$$

境界伸長状態の定義より

$$
L=l_{01}+l_{02}+4 c D+e\left(k_{i}\right) D
$$

(57)式に(53)〜(56)式党代入して

$$
\begin{aligned}
L=2 & \sqrt{\left(y_{c 1}\left(k_{i}\right)-h D\right)^{2}+(h D)^{2}}+\frac{y_{c 2}}{2}-h D \\
& +4\left(\frac{\pi}{\sqrt{2}} D\right)+\sqrt{\left(\frac{y_{c 2}\left(k_{i}\right)}{2}-h D\right)^{2}+\left(\alpha_{i} D\right)^{2}}
\end{aligned}
$$

$y_{c 1}, y_{c 2}$ はいずれも $k_{i}$ をパラメーターとして， 158式上 (37)または(38)式上の連立方程式を解いて决定される。また ウエール力问の采の $\mathrm{X}_{1}$ 軸からの傾き角 $\phi_{c}$ む $1 \times 1$ リブ の場合上同様(33)式で表わされる.

以上のように，インターロック編布の境界伸長状態に おける構造モデルは1×1リブ編布の構造モデルに比べて 表裏の重なりのため幾何学的な制限条件が多く，比較的 単純にモデルの構造定数を决定できる。

境界伸長比 $\lambda_{c 1}, \lambda_{c 2}$ は求まった $y_{c 1}, y_{c 2}$ 学(39)式に代 人して求まる。具体的な計算法は後述する。

\section{4 .2 糸の曲げ効果領域の構造モデル}

境界伸長状態に至るまでの，杀の曲げ上枦じりが伸長 に寄与する領域での構造モデル上して，第23図に示すよ うに，平編構造や前述の1×1リブ構造の場合上同様に， ウエール方问の系はまっすぐで，コース方向の系のみが 曲がっているモデルを適用し，4本のまっすぐ棒と 2 個 の冈孤状曲がり細棒の組み合わせで構成する。すなわち $\mathrm{X}_{2}$ 軸方向にそった $(\mathrm{A})$ 部分の杀の曲がりと，表塞圭つな ぐリンク $(\mathrm{B})$ 部分（図のように $\mathrm{X}_{1} \mathrm{X}_{2}$ 平面から $\theta_{0}$ 傾き, $\mathrm{X}_{2} \mathrm{X}_{3}$ 平面に垂直な平面内にある) 加ら成る。この(B)部 分のリンクは $1 \times 1$ リブ構造では非常に短く, 糸の巻きつ き部分として計算されたが，表裏が交差するインターロ ック構造ではこの部分む 1 つのリンクとしてその曲がり 


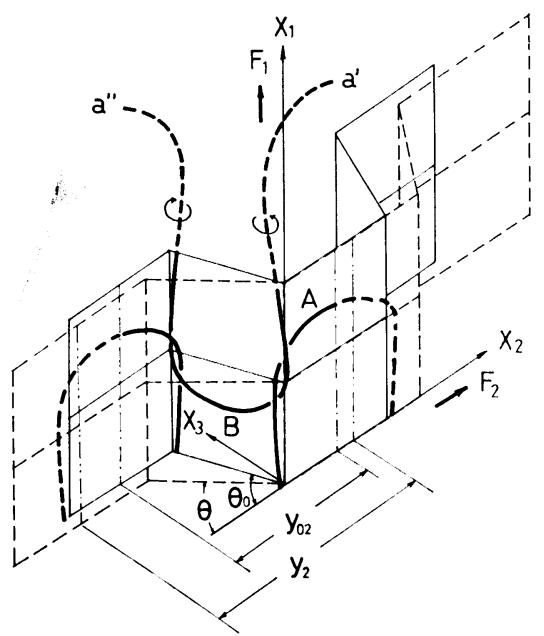

（第23困）インターロック編布の曲げ効果領域 の構造モデル

の伸びが考慮されねばならない。

$1 \times 1$ リブ構造では $P S$ が伸長過程を通じて一定值を とる構造モデルを用いたが，インターロック編布ではこ の領域でリンクが $\theta_{0}$ から $\theta_{c}$ まで回転すると同時に 采の曲がりが伸ばされて $\overrightarrow{P S}$ が增加する.
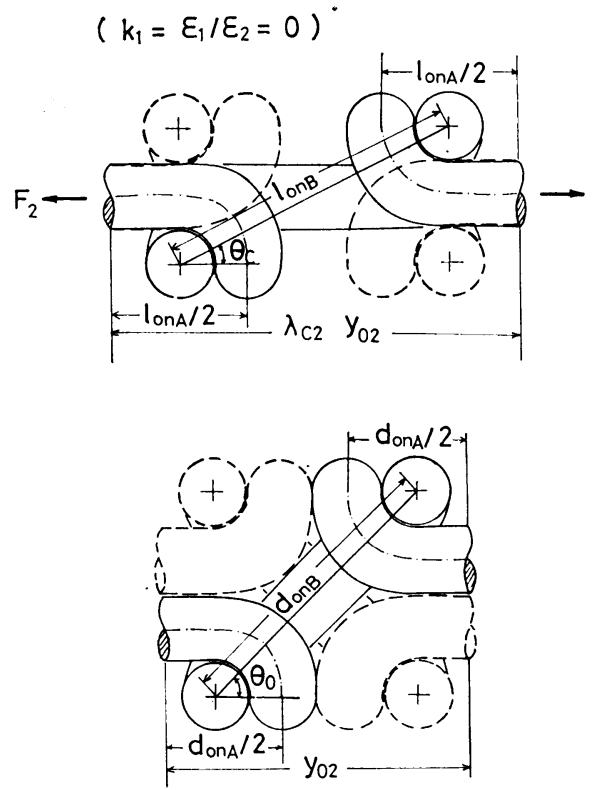

（第24図）インターロック編布の曲げ効果領域 の基準構造モデル

(A)，(B)部分の円孤状曲がり棒の長さ $l_{0 A}, l_{0 B}$ や弦の 長さ $d_{0 A}, d_{0 B}$ は第 24 図に示すように前述の $1 \times 1$ リブ構 造の場合と同様の方法で次のように定める. $k_{1}=0$ を基本変形様式とし，その境界伸長状態での単 位構造を基淮として，この伸長状態から伸長を厌して変 形前の状態に夻したときの構造を第23図の円孤之まっす ぐ棒で構成させ，各定数を次式で求める.

$$
\begin{aligned}
& l_{0 n A}=\frac{\lambda_{c 2}\left(k_{1}=0\right) y_{02}}{2}+h D \\
& l_{0 n B}=\frac{l_{0 n A}}{\cos \theta_{c}\left(k_{1}=0\right)} \\
& d_{0 n A}=y_{02}-D \\
& d_{0 n B}=\frac{D(2 h+1)}{\cos \theta_{0}}
\end{aligned}
$$

冈孤の固定端角度 $\theta_{0 n}$ は

$$
\begin{aligned}
& \theta_{0 n A}=\frac{\sin \theta_{0 n A} l_{0 n A}}{d_{0 n A}} \\
& \theta_{0 n B}=-\frac{\sin \theta_{0 n B} l_{0 n B}}{d_{0 n B}}
\end{aligned}
$$

上述の $k_{1}=0$ 以外の二軸伸長時では, $1 \times 1$ リブ構造 モデルと同様に，両端固定の円孤とまっすぐ棒を組み合 わせ， $\lambda_{1}(-1)$ を与えた状態で $\mathrm{X}_{2}$ 方向に弛緩した状態 下で曲率 $K_{\mathbf{0}}$ の回孤になるモデルを設定する。 そして 与えられた $\lambda_{2}$ まで伸長して円孤の曲げが伸びた状態が 境界伸長時のモデルを与える。

$l_{0 A}\left(\lambda_{1}\right) ; \lambda_{1}$ を与えた状態での(A)部分の円孤の長さ

$\theta_{0 A}\left(\lambda_{1}\right) ;$ 同じく円孤の固定端角度

$d_{0 A}\left(\lambda_{1}\right)$; 同じく $\mathrm{X}_{2}$ 軸力向の力が 0 の弛緩した状態 での円孤の弦の長さ

以下(B)についても同様.

$$
\begin{aligned}
& l_{0 A}\left(\lambda_{1}\right)=\frac{\lambda_{c 2}\left(\lambda_{1}\right) y_{02}}{2}+h D \\
& l_{0 B}\left(\lambda_{1}\right)=\frac{l_{0 A}\left(\lambda_{1}\right)}{\cos \theta_{c}\left(\lambda_{1}\right)} \\
& \theta_{0 A}\left(\lambda_{1}\right)=\theta_{0 n A} \frac{l_{0 A}\left(\lambda_{1}\right)}{l_{0 n A}} \\
& \theta_{0 B}\left(\lambda_{1}\right)=\theta_{0 n B} \frac{l_{0 B}\left(\lambda_{1}\right)}{l_{0 n B}} \\
& d_{0 A}\left(\lambda_{1}\right)=l_{0 A}\left(\lambda_{1}\right) \frac{\sin \theta_{0 A}\left(\lambda_{1}\right)}{\theta_{0 A}\left(\lambda_{1}\right)} \\
& d_{0 B}\left(\lambda_{1}\right)=l_{0 B}\left(\lambda_{1}\right) \frac{\sin \theta_{0 B}\left(\lambda_{1}\right)}{\theta_{0 B}\left(\lambda_{1}\right)}
\end{aligned}
$$

ここで，ウエール方向に $\lambda_{1}$ の伸長を与えた状態で境 界伸長まで $\mathrm{X}_{2}$ 方向に伸長を与えたとき，その伸長比 $\lambda_{c 2}$ は $\lambda_{1}$ の関数 $\lambda_{c 2}\left(\lambda_{1}\right)$ であり，また $\lambda_{1}=\lambda_{c 1}$ になる. また, その状態での $\theta_{c}$ む $\lambda_{1}$ の関数で, 次の方法で求 まる・

与えられた $k_{i}$ と構造定数から，まず $\lambda_{c 1}$ と $\lambda_{c 2}$ の関 係を炏節に述へる方法により計算し， $\lambda_{1}=\lambda_{c 1}$ に対忘 する $\lambda_{c 2}$ を求める. との $\lambda_{c 2}$ と $\lambda_{1}$ を(10)式に代入して $k_{i}$ を求め，さらにこの $k_{i}$ を(50)および(16)式に代入して $\theta_{c}\left(\lambda_{1}\right)$ が求まる。 


\section{3. 境界伸長比の計算法}

任意の変形様式 $k_{i}$ 在与えたときの境界伸長比は前述 のように境界伸長時の構造モデルから臫かれるが，その 計算方法について述べ.

\section{1 四式解法}

$1 \times 1$ リブ編布の場合；

$k_{1}$ をパラメーターとする場合は，(37)式上(36)式を変形 した(71)式との連立方程式

$$
y_{c 1}=k_{1} y_{c 2} \frac{y_{01}}{y_{02}}+y_{01}\left(1-k_{1}\right)
$$

$y_{c 1}=$

$$
\begin{aligned}
& \left.\sqrt{\left(\frac{L-y_{02}-4 c\left(k_{1}\right) D-e\left(k_{1}\right) D+\sqrt{h^{2}+3^{2}}}{2} \cos \theta_{c}\left(k_{1}\right)\right.}\right)^{2} \\
& -(h D)^{2}+h D
\end{aligned}
$$

を $y_{c 1}, y_{c 2}$ について解き, その解から $\lambda_{c 1}\left(k_{1}\right), \lambda_{c 2}\left(k_{1}\right)$ は(39)式で得られる.この解を得る一つの方法上して図式 解法がある。

まず， (37)式で $y_{c 2}$ を与えて $y_{c 1}$ を計算する. そして その関係を第25四のように描く.

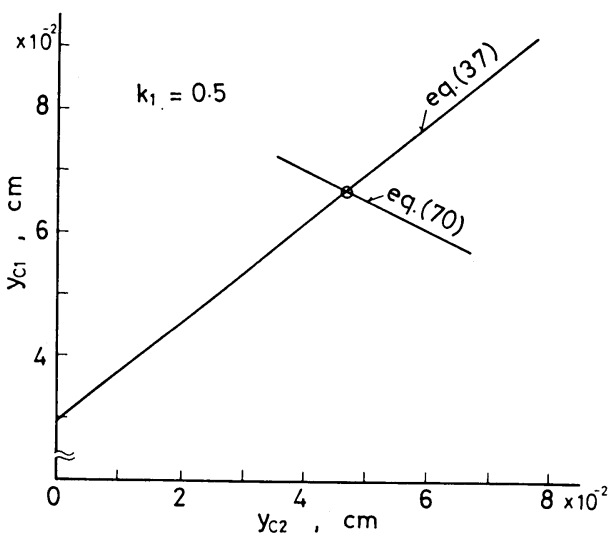

（第25図） $y_{c 1} ， y_{c 2}$ の仳式解法（計算例）

(37)式の各定数は構造定数によって沈まる. 次に，(70)式 についても同様に $y_{c 2}$ に対する $y_{c 1}$ 在計算して同罒中 に描く. (37)式，(71式在満足する $y_{c 1} ， y_{c 2}$ の值は $2 つ 0$ 曲線の交点で求まる。

$k_{2}$ をパラメーター上する場合についても同様に，(36) 式を変形した(72)式と(38)式の連立方程式を $y_{c 1}, y_{c 2}$ につ いて解く.すなわち

$$
\begin{aligned}
y_{c 2}= & k_{2} y_{c 1} \frac{y_{02}}{y_{01}}+y_{02}\left(1-k_{2}\right) \\
y_{c 2}= & L-2 \sqrt{\left(y_{c 1}-h D\right)^{2}+(h D)^{2}}-4 c\left(k_{2}\right) D \\
& -e\left(k_{2}\right) D+\sqrt{h^{2}+3^{2}} D_{\cos } \theta_{c}\left(k_{2}\right) \cdots \cdots
\end{aligned}
$$

困式的に解く方法は前述と同様である. その解を(39)式 に代入して $\lambda_{c 1}\left(k_{2}\right), \lambda_{c 2}\left(k_{2}\right)$ を計算する.
インターロック編布の場合；

インターロック編布でも前述の $1 \times 1$ リブ編布の場合と 同様の手法で $y_{c 1} ， y_{c 2}$ を眓式的に解くことができる.

$k_{1}$ をパラメーターとする場合は，(37)式，(71)式に代わ って次の (37)式上 (36)式変形した (73)式との連立方程式在 $y_{c 1}, y_{c 2}$ について解く.

$$
\begin{aligned}
& y_{c 1}=k_{1} y_{c 2} \frac{y_{01}}{y_{02}}+y_{01}\left(1-k_{1}\right) \quad \ldots \cdots \cdots(37) \\
& \left.y_{c 1}=\sqrt{\left(L-7 h D-\frac{y_{c 2}}{2}-\sqrt{\left(\frac{y_{c 2}}{2}-h D\right)^{2}+\left(\frac{k_{1}}{2} D\right)^{2}}\right.}\right)^{2} \\
& -(h D)^{2}+h D
\end{aligned}
$$

(73)式は前述の (36)式を変形して (16)式を代入したものであ る.

$k_{2}$ をパラメーターよする場合（ただし， $k_{2}=0$ を除 く）は，(38)式，(72)式に代わって次の(74)式上(75)式上の連立 方程式を解く.

$$
\begin{aligned}
& y_{c 1}=\frac{y_{01}}{y_{02}} \frac{1}{k_{2}}\left\{y_{c 2}-y_{02}\left(1-k_{2}\right)\right\} \quad \ldots \cdots \cdots(74) \\
& y_{c 1}= \\
& \begin{array}{c}
\sqrt{\left(\frac{L-7 h D-\frac{y_{c 2}}{2}-\sqrt{\left(\frac{y_{c 2}}{2}-h D\right)^{2}+\left(D-\frac{k_{2}}{2} D\right)^{2}}}{2}\right)^{2}} \\
\wedge-(h D)^{2}+h D \\
\cdots \cdots \cdots(75)
\end{array}
\end{aligned}
$$

(74)式は(38)式在変形したものであり，(75)式は(36)式を変形し て(16)式在代入したものである。

$k_{2}=0$ の変形栚式では， $y_{c 2}=y_{02}$ であるから，その関 係索(75)式に代人して直与に $y_{c 1}$ が求まる.

\section{2 コンピューターによる解法}

コンピューターによって, 上述の連立力程式の解 $\boldsymbol{y}_{c 1}$, $y_{c 2}$ 在求好方法として，一つは前述の図式的に交点在 求めて連立方程式在解く順序をそのままコンピューター でデジタル力式で尖行させる力法上，他の一つはニュー トン法などにより連立方程式の根の近似解党得る力法が ある・

後者のニュートン法を用いる方法については付録に示 しているが，この方法でも存効数字 7 析以上の近似解が 前者の方法上りも短時間の計算時間で得られるから们用 である。

ニュートン法による近似解法は初期值を $y_{01}, y_{02}$ に とり，第20近似を行なうことによって十分の精度の結果 が得られる。

\section{4. 計算例}

境界伸長比は編布の伸長特性の理論計算のために設け た仮想の值であるが，曲がった糸がまっすぐに伸びきる 伸長比であるから構造があつ一種の最大伸長比であって 
編布の実用性能在検討するうえでも重要な特性值であ る.

平編，1×1リブ編，インターロック編など編組織の遠 いが境界伸長比をどの程度変化させるか，また構造定数 が境界伸長比におよぼす効果についての計算例在以下に 示す.

4.1 組織の異なるよこ編布の境界伸長比

境界伸長比の計算には，すでに示したようにウエール 数, コース数, ループ長, 禾の太さがわかればよい.

30’s の羊毛系を例䎲とり, 采の太さ: $D=0.01621 \mathrm{~cm}$ $1 \mathrm{~cm}$ 当たりのコース数: $C=16$ として, 平編, $1 \times 1$ リ ブ編，インターロック編布の構造定数を次のように定め て計算に用いた。

一般に， $C, W, L$ の間には拘束された関係があり， この関係は各組織について実験的に見いだされている。

平編構造には，乾燥緩和したそ毛系について D. L. Munden $^{13)}$ によって游かれている次式在適用して $W$, $L^{\prime}$ を定める.

$$
\begin{aligned}
& C=5.00 \frac{1}{2.54 L^{\prime}} \\
& W=3.80-\frac{1}{2.54 L^{\prime}}
\end{aligned}
$$

ただし， $L^{\prime}=2 L$ である.

$1 \times 1$ リブ構造では J. A. Smirfitt" に上るそ毛采の 乾燥緩和した編布において得られている次式在適用して $R, L^{\prime}$ を定好。

$$
\begin{aligned}
& C=4.51 \frac{1}{2.54 L^{\prime}} \\
& R=3.34 \frac{1}{2.54 L^{\prime}}
\end{aligned}
$$

$1 \times 1$ リブ構造では $L=L^{\prime}$ である.

インターロック編布については, 以上のような定数は 一定でなく， $L^{\prime}$ や編布緩和状態によって変わるとされ ているが，十分緩和した状態には，J. F. Knapton ${ }^{81}$ に よって示さ机ている次式者適用して $W, L^{\prime}$ を定める.

$$
\begin{array}{rlr}
C & =1.02 & \cdots \cdots \cdots(80) \\
W & \\
W C & =\frac{375}{\left(2.54 L^{\prime}\right)^{2}} & \cdots \cdots \cdots(81)
\end{array}
$$

ただし，インターロック編布では $L^{\prime}-4 L$ である。

以上の上うにして定めた編組織别のウエール数 $W$ 上

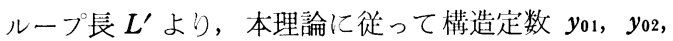
$L$ を計算してデータとして与え, コンピューターによっ て計算した結果の $\lambda_{c 1}$ 之 $\lambda_{c 2}$ の関係を第26図に示してい る.

平編布の境界伸長比の計算法す，すでに報告した理論 計算法をコンピューター化して行なっている.

同じ太さの系で,コース数をそろえて適度の編密度に 編まれた編組織の異なるよ乙編布の境界伸長比におよば

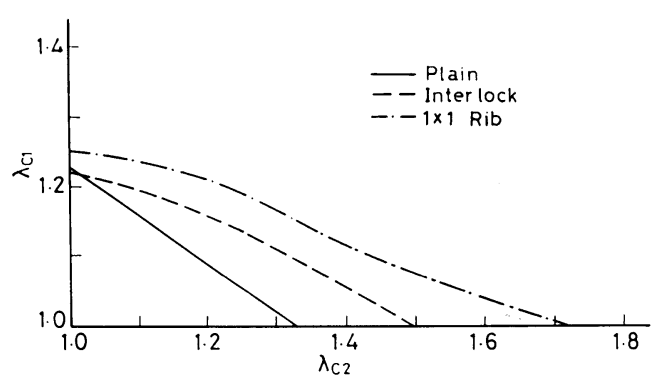

（第26図）組織の異なるよこ編布の境界伸長比

す編布構造組織の効果が計算例から明らかである。

4.2 編密度が境界伸長比におよぼす効果

編構造の粗密が境界伸長比におよ活す効果をみるため $1 \times 1$ リブおよびィンターロックについて，系の太さ $D$ は一定として, 前項の計算に用いた構造定数を基淮とし て， $L^{\prime} を \pm 10 \%$ 変化させたとき，境界伸長比に現われ る効果を計算した。ただし， $C, R, W$ などは $1 \times 1$ リブ の場合は(78)，(79.式で，インターロックの場合は180，，181式 で計算した。第 27 四は $1 \times 1$ リブ編布, 第 28 図はインタ 一ロック編布についての計算例である・ループ長の影響 はかなり大きい。

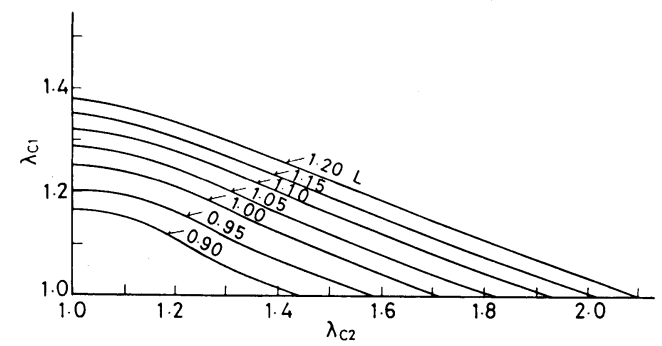

（第27困） $1 \times 1$ リブ編布の編密度が境界伸長比におよほ す奻果 $(L ;$ 単位構造中の糸長, $=0.2844 \mathrm{~cm}$ 在標淮としてその倍数で变化を示す)

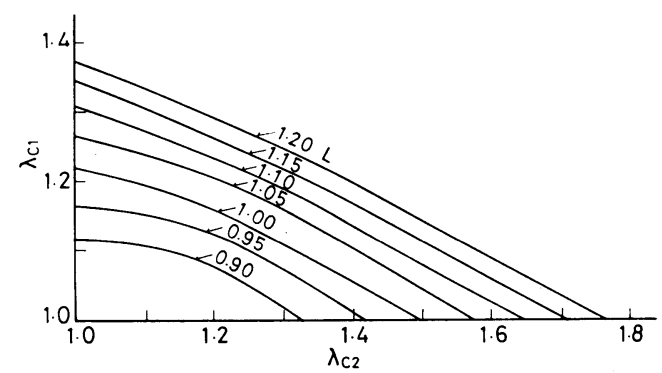

（第28図）インターロック編布の編密度が境界伸長比に 㧍よばす効果

$(L$; 単位構造中の糸長, $=0.3083 \mathrm{~cm}$ 在標淮 としてその倍数で変化を示す) 


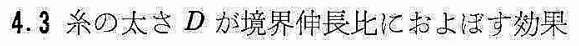

4.1 の計算に用いた棈造定数のうち 系の太さ $D$ を土 10\%変化させて，条の太さが境界伸長比に求よはす効罢 在計算し，第29函に $1 \times 1$ リブ編布，第30図にインター 口ック編布の計算例宗す。編密度が等しく，来の太さ が異なる場合，糸の太さが境界伸長比を大きく左右する ととがわかる。

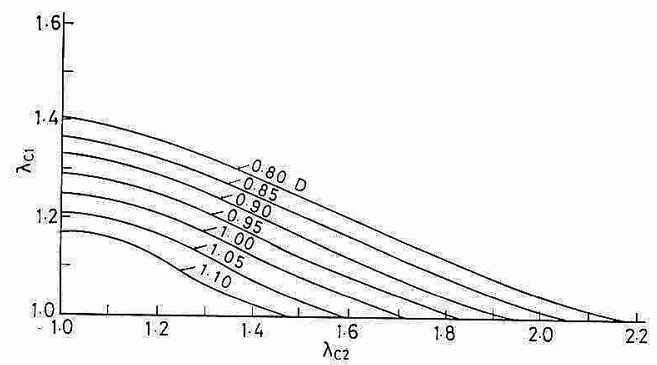

(第29図) $1 \times 1$ リブ編布の杀の太さ $D$ が境界体長比に およばす效果 $(D=0.01621 \mathrm{~cm}$ 老標準しして その信数で变化を示す)

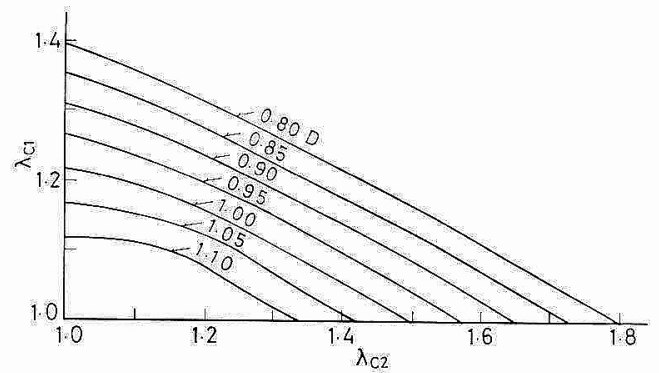

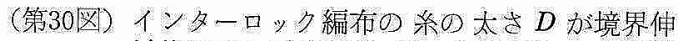
長比におよにす効果 $(D=0.01621 \mathrm{~cm}$ を標淮 として，その倍数で变化子示す)

以上の达うに，境界伸長比は理論的に容易代計算され るが，この值は編布の伸びきり時の伸長比を与えるので， とれのみで值用目的に応じた編布構造の設計の目やす に役立つであろう.

\section{5. 考 察}

5.1 境界伸長時の棈造モデルについて

境界伸長時のリンクの $\mathrm{X}_{2}$ 軸为らの儧き角 $\theta_{c}\left(k_{i}\right)$ の 決定は，1×1リブ構造の場合は怊式だ，インターロック 編布の場合は50式てそれぞれ近似して推定しているが, これらは $\mathrm{X}_{2} \mathrm{X}_{3}$ 平面内て，幾何学的ととり得る形態の 制限をむと設設した一つか推定方法である.

各種の $1 \times 1$ リ゙編布について，各種の二軸変形様式 下での伸長江伴う $\mathrm{X}_{2} \mathrm{X}_{3}$ 平面で或っ断面の棈造变化 を瀕微鏡写真で観测し， をの $\theta_{c}\left(k_{i}\right)$ を第31図にプロッ トした。 177式による推定法実際の值に比較的忠实です るととが踓妿められた。

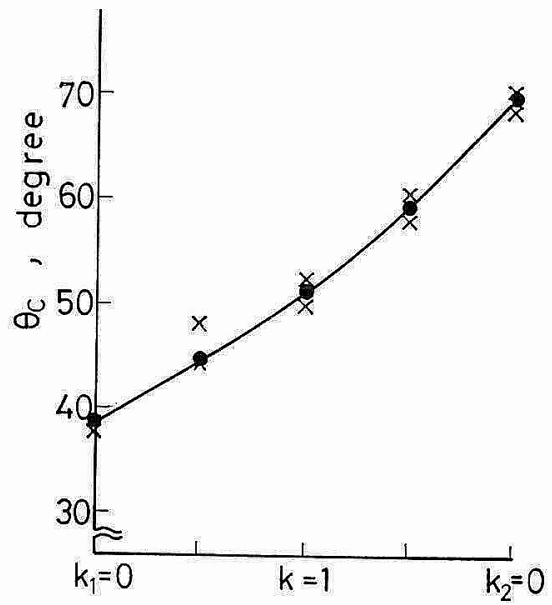

(第31雨) $1 \times 1$ リブ編布における $\theta_{c}\left(k_{i}\right)$ の観測値 乙計算值

同様にして，インターロック編布についても実測し， (50式の) $\theta_{c}\left(k_{i}\right)$ 值の推定も正確であるととを確認してい 了。

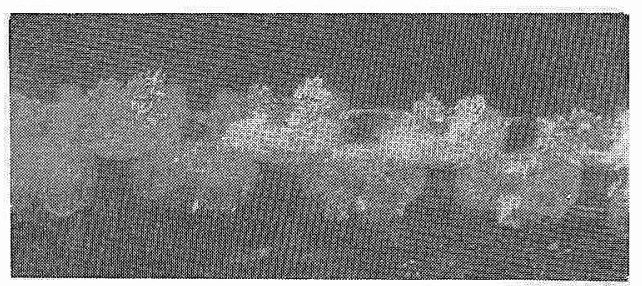

(a) $k_{2}=0$

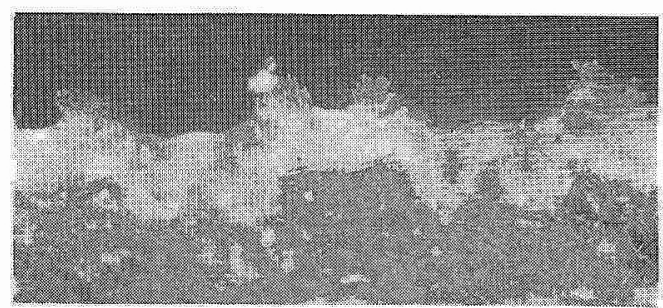

(b) $k_{\mathbf{i}}=0$

(第32因) $1 \times 1$ リ゙編布の境界伸長状態ての $\mathrm{X}_{2}, \mathrm{X}_{3}$ 平面の形状

欣に，境界伸辰時，交差部分ての杀の巻さつき長さの 㹟定法に関して， $1 \times 1$ リ゙編布の場合は2つの部分，第 一種と第二種の部分に分離した。第二種の部分がとん

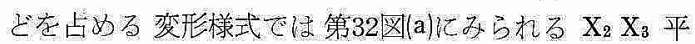
面の断面写真からわかるように $\mathrm{X}_{3}$ 軸力向に給が压縮さ れ円管の半程が $D$ よりも小さい值とっている. この ような観測結果を各種の1×1リブ編布について行ない, とれらをもをに28)式の $c_{2}\left(k_{i}\right)$ 值を修正したのが第15四 の点線て，乙の修正しよって1×1リブ構造編布はす心 
ての変形様式でその境界伸長比がさらに正確に計算でき ることが確認された。

インターロック編布の場合は, 糸の卷きつき形状はす べての変形様式を通じて平編布の卷きつき形状にひとし い構造モデルを組み立てているが，ての妥当性は次節で 示す境界伸長比の計算結果之二軸伸長特性の実測結果か ら明らかである。

5.2 境界伸長比の計算結果之二軸伸長特性の実測結果 の比較

境界伸長比の理論計算結果が妥当な值であるかどうか の検討は，境界伸長状態以前と以後の伸長領域の特性を 計算し, 両者の合成曲線, 古なわち二軸伸長特性の理論 計算結果と実测結果を比較してはじわて明確になること であるが，乙の検討は別報で示すととにし，ここでは二 軸伸長特性の実測值上計算值に境界伸長比の計算值を記 入してその值の妥当性の一例を示している.

第 33 図は $1 \times 1$ リブ編布の変形様式を異にした二軸伸 長特性之その境界伸長比を，第34図はインターロック編 布の場合の一例走している.

各種の編布について第33，34眓之同傾向のみられるこ とを確認している.
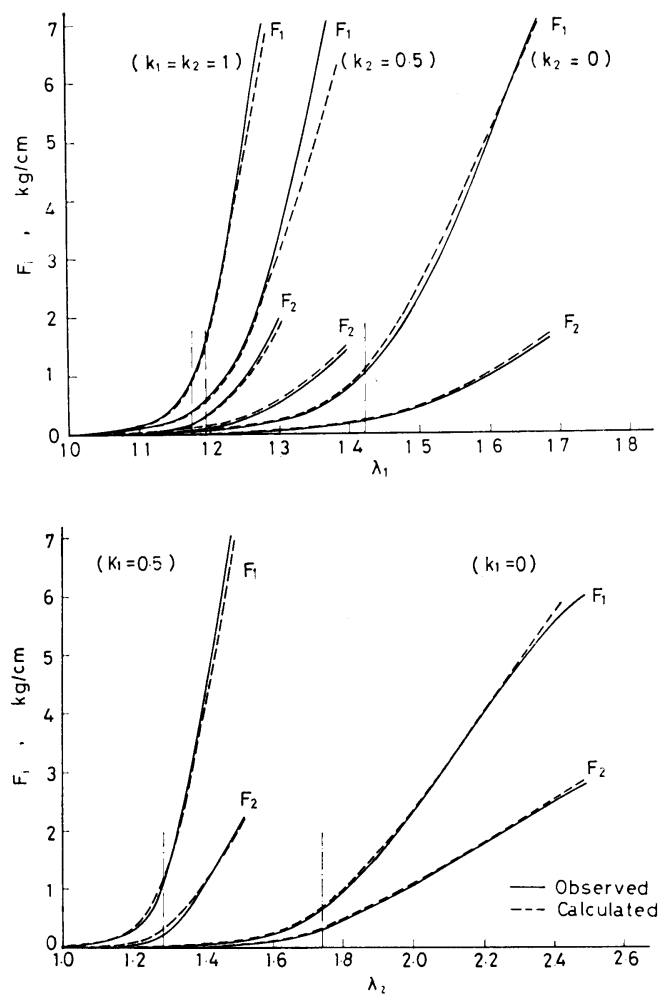

(第33困) $1 \times 1$ リブ編布の各種変形様式下での二軸 伸長特性と境界伸長比の計算例，ポリエ ステル $150 \mathrm{den}$, リブ数 $14.0 \mathrm{~cm}^{-1}, コ ー$ ス数 $17.2 \mathrm{~cm}^{-1}$

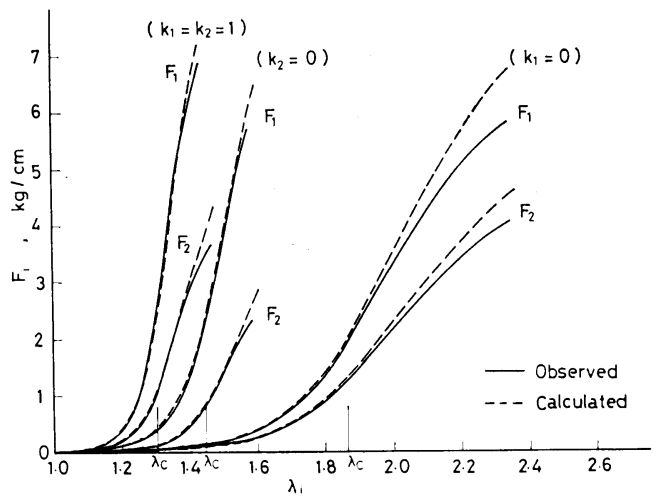

（第34戝）インターロック編布の二軸伸長特性上境界伸 長比の計算例, 羊毛 36 's, ウエール数 $11.9 \mathrm{~cm}^{-1}$, コース数 $12.4 \mathrm{~cm}^{-1}$

5.3 曲げ訤果領域の構造モデルについて

$\theta_{0}$ は本理論では采の曲㓠およびねじり効果の計算に 桴入される初期值として重要である. $1 \times 1$ リブ編布では (7)式で，インターロック編布では(49)式で与えた。

$1 \times 1$ リブ編布では，J. A. Smirfitt" によると， $\theta_{0}=$

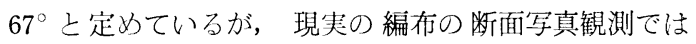
$\theta_{0}$ 泣他の構造定数の起いによって一定せず上記の值よ りかなり大きい值をむつものが多い.(7)式の決定方法は 写真観測結果上よく一致している.

インターロック編布についても同様で， $\theta_{0}=56.4^{\circ}$ 上 いう仮定が示されているが10)，乙の值は本理論の(49)式で 求められる值とは多少異なる.

本理論の $\theta_{0}$ 值は曲壮効果領域の構造モデルを正碓な 境界伸長状態飞連結するための值でもあり，乙れが現尘 の值と近い值をむつことは構造モデルがかなり現実構造 に近いととを示している。

\section{6. 結 語}

リブ構造をむつ編布の基本組織である $1 \times 1$ リブ編布 とインターロック編布について，その伸長特性の精度高 い理論計算を得るための構造モデルを設定し，そのモデ ルの各定数を军際の構造定数から決定する方法を提出し た。

本理論では，境界伸長状態のモデルを基集にして，そ の伸長比以下の曲げ効果領域之, その伸長比を越えた禾 伸長効果領域を分離し, 別個の構造モデルによって伸長 特性を誘導し，後にこれらを合成する方法をとってい る.したがって, 基淮となる境界伸長状態での立体構造 モデルをまず戦密に組み立てる必要があるが，逆にこの ために曲げ効果領域のモデルは簡単化できる特長があ る. そして被雑な幾何学形態をむつ編布の力学特性の解 析老比較的簡単にできる.

これらの構造モデルを用いて編布の伸長特性の理論計 
算がすでに発表した方法在応用して直ちに実行できる.

そしてモデルの妥当性については, すでに理論計算結果

と，実測結果之の間のよい適合性によって確認している が，こ机らに関しては別報にゆずる.

終わりに，本研究に対し有益な御討論，示唆をいただ いた京都大学工学部高分子化学教室内繊維集合体力学研 究会の諸氏に深く感謝の意を表わす。

\section{文献}

1) 川端, 于妆, 七島, 河合; 織機誌, 32, T95 (1970)

2）州羽, 川端, 七岛, 河合; 絨機誌, 23, T120 (1970)

3）川端, 丹羽, 七島, 河合; 絨機誌, 23, T223 (1970)

4) J. A. Smirfitt ; J. Text. Inst., 56, T248 (1965)

5) G. A. V. Leaf : J. Text. Inst., 51, T49 (1960)

6) J. A. Smirfitt ; J. Text. Inst., 56, T298 (1965)

7) J. M. Jacob; Ann. Sci. Text. Belges, No. 1, 75 (1965), No. 4, 1 (1966)

8) J. F. Knapton ; XII Congress of the International Federation of Knitting Specialists, Proc. (1967)

9) J. F. Knapton, D. L. Munden ; Text. Res. J., 36, 1072, 1081 (1966)

10) J. W. S. Hearle, P. Grosberg, S. Backer ; Structural Yarns and Fabrics, Vol. 1, Wiley-Interscience, p. 434 (1969)

11) T. S. Nutting, G. A. V. Leaf ; J. Text. Inst., 55, T45 (1964)

12）川端季雄; 繊機誌, 23, T30（1970）

13) D. L. Munden ; J. Text. Inst., 50, T448 (1959)

\section{付 録}

二ュートン法による境界伸長比の近似解法

\section{$1 \times 1$ リブ編布の場合；}

構造定数 $y_{01}, y_{02}, L, D$ 上任意の変形様式 $k_{i}$ にお ける $c\left(k_{i}\right), e\left(k_{i}\right)$ をデータとして与え， $k_{i}$ に対する境 界伸長比 $\lambda_{c 1}\left(k_{i}\right), \lambda_{c 2}\left(k_{i}\right)$ 在次のようにしてコンピュー ターによって計算する。

$k_{1}$ をパラメーター上する上き，すな⿰七 $\varepsilon_{1} \varepsilon_{2}$ の変 形様式では，(37)，(71式から $y_{c 1}$ を消去して $f\left(y_{c 2}\right)=k_{1} \frac{y_{01}}{y_{02}} y_{c 2}+\left(1+k_{1}\right) y_{01}-h D-$

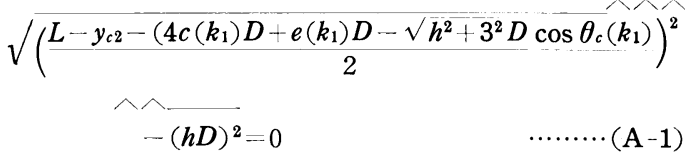
または，

$$
f\left(y_{c 2}\right)=A_{1} y_{c 2}+A_{2}-A_{4}-\sqrt{\left(\frac{A_{3}-y_{c 2}}{2}\right)^{2}-A_{4}^{2}}=0
$$

ただし，

$$
\begin{aligned}
& A_{1}=\frac{k_{1} y_{01}}{y_{02}} \\
& A_{2}=\left(1-k_{1}\right) y_{01} \\
& A_{3}=L-\left\{4 c\left(k_{1}\right) D+e\left(k_{1}\right) D-\sqrt{h^{2}+3^{2}} D \cos \theta_{c}\left(k_{1}\right)\right\} \\
& A_{4}=h D
\end{aligned}
$$

(A-2) 式の根 $y_{c 2}$ は (A-2) 式を微分して

$$
\frac{d f\left(y_{c 2}\right)}{d y_{c 2}}=A_{1}-\frac{y_{c 2}-A_{3}}{4 \sqrt{\left(\frac{A_{3}-y_{c 2}}{2}\right)^{2}-A_{4}{ }^{2}}}
$$

(A-2)，(A-3) 式よりニュートン法老用いて $y_{c 2}$ の第20 近似もとれば十分な精度の近似值が得られる.すなわち

$$
\begin{aligned}
& {\left[y_{c 2}\right]_{1}=y_{02}} \\
& {\left[y_{c 2}\right]_{20}=\left[y_{c 2}\right]_{19}-\frac{f\left(\left[y_{c 2}\right]_{19}\right)}{d f\left(\left[y_{c 2}\right]_{19}\right)}} \\
& d\left[y_{c 2}\right]_{19}
\end{aligned}
$$

一方,

$$
\begin{aligned}
& g\left(y_{c 2}\right)=y_{c 1} \text { とすると, (37)式より } \\
& g\left(\left[y_{c 2} \mathbf{2 0}_{20}\right)=A_{1}\left[\boldsymbol{y}_{c \mathbf{2}} \mathbf{2 0}_{\mathbf{2 0}}+A_{\mathbf{2}}\right.\right.
\end{aligned}
$$

これらより，

$$
\lambda_{c 1}\left(k_{1}\right)=\frac{g\left(\left\lceil y_{c 2}\right\rfloor_{20}\right)}{y_{01}}, \lambda_{c 2}\left(k_{1}\right)=\frac{\left[y_{c 2}\right]_{20}}{y_{02}}
$$

$k_{2}$ をパラメーターとする場合，すなわち $\varepsilon_{1} \geq \varepsilon_{2}$ の変 形様式では，(38)と(72)式から $y_{c 2}$ を消去し，

$$
f\left(y_{c 1}\right)=B_{1} y_{c 1}+B_{2}+2 \sqrt{\left(y_{c 1}-A_{4}\right)^{2}+A_{4}^{2}}+B_{3}=0
$$

ただし

$$
\begin{aligned}
& B_{1}=\begin{array}{l}
k_{2} y_{02} \\
y_{01}
\end{array} \\
& B_{2}=\left(1-k_{2}\right) y_{02} \\
& B_{3}=4 c\left(k_{2}\right) D+e\left(k_{2}\right) D-\sqrt{h^{2}+3^{2}} D \cos \theta_{c}\left(k_{2}\right)-L
\end{aligned}
$$

(A-8) 式の根 $y_{c 1}$ は, (A-8) 式を微分して

$$
\frac{d f\left(y_{c 1}\right)}{d y_{c 1}}=B_{1}+\frac{2\left(y_{c 1}-A_{4}\right)}{\sqrt{ }\left(y_{c 1}-A_{4}\right)^{2}+A_{4}^{2}}
$$

前述の方法上同様に（A-8），(A-9) 式上り，ニュート ン法を用いて $y_{c 1}$ の第 20 近似在求わる。すなおち,

$$
\begin{aligned}
& {\left[y_{c 1}\right]_{1}=y_{01}} \\
& {\left[y_{c 1}\right]_{20}=\left[y_{c 1}\right]_{19}-\frac{f\left(\left[y_{c 1}\right]_{19}\right)}{d f\left(\left[y_{c 1}\right]_{19}\right)}} \\
& d\left[y_{c 1}\right]_{19} \\
& g\left(y_{c 1}\right)=y_{c 2} \text { 上すると, (38)式より, } \\
& g\left(\left[y_{c 1}\right]_{20}\right)=B_{1}\left[y_{c 1}\right]_{20}+B_{2}
\end{aligned}
$$

これらより，

$$
\lambda_{c 1}\left(k_{2}\right)=\frac{\left[y_{c 1}\right]_{20}}{y_{01}}, \lambda_{c 2}\left(k_{2}\right)=\frac{g\left(\left[y_{c 1}\right]_{20}\right)}{y_{02}}
$$

インターロック編布の場合；

構造定数 $y_{01}, y_{02}, L, D$ のみをデータとして与え， 任意の変形様式 $k_{i}$ にお打る $\lambda_{c 1}\left(k_{i}\right), \lambda_{c 2}\left(k_{i}\right)$ は, $1 \times 1$ リブ編布の場合之同様の方法で計算できる. 
まず， $k_{i}$ をパラメーターとする場合は， (37)，(73式から $y_{c 1}$ を消去した次の（A-14） 式之（A-14）式走微分した（A-15）式とか ら, ニュートン法を用いて（A-14）式の根 $y_{c 2}$ の近似解求よび $y_{c 1}$ を $1 \times 1$ リブと同様に 計算し，(A-6) 式で $y_{c 1}$ 在求めて，(A-7) 式で $\lambda_{c 1}\left(k_{1}\right) \lambda_{c 2}\left(k_{1}\right)$ 在計算する。

$f\left(y_{c 2}\right)=A_{1} y_{c 2}+A_{2}-A_{4}$

$$
-\frac{1}{2} \sqrt{\left\{A_{7}-0.5 y_{c 2}-\sqrt{\left(0.5 y_{c 2}-A_{4}\right)^{2}+A_{6}}\right\}^{2}-4 A_{4}{ }^{2}}
$$$$
=0
$$

$$
\begin{aligned}
& \frac{d f\left(y_{c 2}\right)}{d y_{c 2}}=A_{1}
\end{aligned}
$$

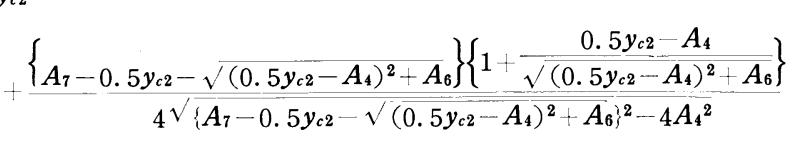

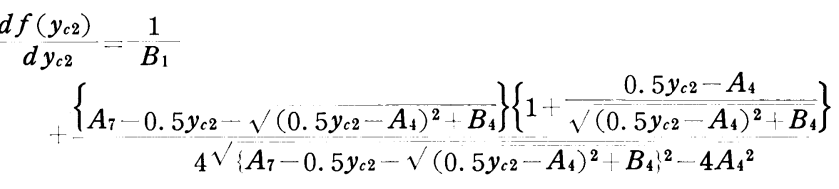
ただし，

$$
\begin{gathered}
B_{4}=\left(D-\frac{k_{2}}{2} D\right)^{2} \\
B_{5}=\frac{B_{2}}{B_{1}}+A_{4} \\
g\left(y_{c 2}\right)=y_{c 1} \text { とすると, (73)式より } \\
g\left(y_{c 2}\right)=\frac{y_{c 2}-B_{2}}{B_{1}}
\end{gathered}
$$

$$
\begin{aligned}
& \text { したがって, } \\
& \quad \lambda_{c 1}\left(k_{2}\right)=\frac{g\left(\left[y_{c 2} y_{20}\right)\right.}{y_{01}}, \lambda_{c 2}\left(k_{2}\right)=\frac{\left\lceil y_{c 2} y_{20}\right.}{y_{02}}
\end{aligned}
$$

$k_{2}=0$ の場合は（A-16）（A-17）式がオ一

ただし，

$$
\begin{aligned}
& A_{6}=\frac{k_{1}}{2} D \\
& A_{7}=L-7 h D
\end{aligned}
$$

$k_{2}$ をパラメーターとする場合は（ただし $k_{2}=0$ 在除 く)，(74）（75式から，やはり $y_{c 1}$ 在消去した次の (A-16) 式とこ机在微分した（A-17）式と在（A-5) 式に代入 して, すなわち二ュートン法により（A-16）式の根 $y_{c 2}$ を計算する。

$$
\begin{array}{r}
f\left(y_{c 2}\right)=\frac{y_{c 2}}{B_{1}}-B_{5} \\
\left.-\frac{1}{2} \sqrt{\left\{A_{7}-0.5 y_{c 2}-\sqrt{ }\left(0.5 y_{c 2}-A_{4}\right)^{2}+B_{4}\right.}\right\}^{2}-4 A_{4}{ }^{2} \\
=0
\end{array}
$$

バーフローによって計算が不能になる。このため(75)式に よって $y_{c 1}$ を求めるプログラムを用いて計算を行なう。 